\title{
STORYTELLING PARA DESENVOLVER LEITURA E ESCRITA: UMA EXPERIÊNCIA DESENVOLVIDA DURANTE A PANDEMIA
}

\section{ARTIGO ORIGINAL}

FLICIDADE, Janaína ${ }^{1}$, SCHLICKMANN, Maria Sirlene Pereira²

FLICIDADE, Janaína. SCHLICKMANN, Maria Sirlene Pereira. Storytelling para desenvolver leitura e escrita: uma experiência desenvolvida durante a pandemia. Revista Científica Multidisciplinar Núcleo do Conhecimento. Ano. 06, Ed. 10, Vol. 01, pp. 96-135. Outubro 2021. ISSN: 2448-0959, Link de acesso: https://www.nucleodoconhecimento.com.br/educacao/storytelling, DOI: 10.32749/nucleodoconhecimento.com.br/educacao/storytelling

\section{RESUMO}

Neste artigo, faz-se um relato do uso da metodologia ativa, Storytelling, em um colégio com ensino remoto, na classe do $1^{\circ}$ ano do ensino fundamental. Nesse sentido, o objetivo é analisar como essa ferramenta (Storytelling) pode contribuir para que a criança, em fase inicial da alfabetização e letramento, aproprie-se dos conhecimentos e, ao mesmo tempo, desenvolva o gosto pela leitura e escrita. A questão norteadora desta pesquisa foi: Como Storytelling pode ser uma ferramenta para o aprendizado ativo, de forma a contribuir, para que a criança, em fase inicial da alfabetização e letramento, aproprie-se dos conhecimentos e ao mesmo tempo desenvolva o gosto pela leitura e escrita? Sabe-se que há diversos métodos de alfabetizar e inúmeras maneiras de letrar, sendo assim, nesta pesquisa, evidenciase, como essa metodologia ativa, está sendo utilizada e aplicada na escola com ensino remoto e em casa com a presença dos pais. Em relação à metodologia utilizada nesta pesquisa, foi o estude de caso do tipo exploratória, com abordagem qualitativa. Os sujeitos da pesquisa foram crianças de 6 e 7 anos de idade. Utilizouse a plataforma Zoom para o desenvolvimento do plano de aula. Com base nisso,

\footnotetext{
${ }^{1}$ Licenciada em Pedagogia e Especialista em Inovação da Educação.

2 Professora. Doutorado em Ciências da Linguagem pelo PPGCL da Universidade do Sul de Santa Catarina.
} 
serviram como instrumentos para a coleta dos dados as produções dos alunos. A partir da análise dos dados, foi possível verificar que a metodologia ativa, storytelling, pode ser uma aliada para o aprendizado ativo e contribuir para a apropriação do conhecimento pelos alunos e, ao mesmo tempo, desenvolver o gosto pela leitura.

Palavras-chave: Metodologia Ativa, Storytelling, Leitura, Escrita, Alfabetização.

\section{INTRODUÇÃO}

Esta pesquisa tem sua essência voltada para a compreensão da aprendizagem e do desenvolvimento da criança, no processo de alfabetização e letramento com foco na Storytelling.

Estudos, principalmente os que se fundam na Proposta Curricular do Estado de Santa Catarina (2014), demonstram que é importante que a criança tenha a necessidade de aprender, em vista disso, ela participa ativamente no processo de construção do seu conhecimento, na fase de alfabetização e letramento. E, com o uso das metodologias ativas, como se propõe nesse trabalho, esse processo tornase prazeroso para a criança. Essas metodologias não são novas, há um bom tempo que vêm sendo discutidas, porém existem alguns professores que, por falta de formação continuada, talvez, ainda, apoiam-se em metodologia ditas "tradicionais", ou seja, exercem papel de transmissores do conteúdo, e nesse paradigma, a criança é apenas o expectador, captador do conteúdo.

O ser humano aprende e se desenvolve, em diversos contexto em que vive, em todo tempo. É evidente que a aprendizagem realizada, na escola, tem uma intencionalidade, que é a apropriação do conhecimento historicamente desenvolvido. Dessa maneira, pode-se dizer que a aprendizagem é um processo de aquisição do conhecimento científico. $\mathrm{O}$ desenvolvimento e a aprendizagem são processos que se dão de forma contínua, na vida do ser humano. 
Convém ressaltar que as novas metodologias, principalmente as que utilizam as Tecnologias de Informação e Comunicação (TICs), vêm como ferramentas de auxílio às aulas do professor. Abrem-se novas possibilidades de "potencializar" a aprendizagem, dado que se sabe que a aprendizagem acontece de muitas formas.

Freire (1989, p. 7) reforça que "[...] aprender a ler, a escrever, alfabetizar-se é, antes de qualquer coisa, aprender a ler o mundo, compreender o seu contexto, não numa manipulação mecânica de palavras, mas numa relação dinâmica que vincula linguagem e realidade".

À vista disso, torna-se importante que o espaço para o ensino e aprendizagem seja organizado em sala de aula, para que a cada momento a criança sinta necessidade de aprender. Considera-se, também, que o tempo é um aspecto importante, na vida de uma escola, e dele depende todo o desenvolvimento do processo de ensino e aprendizagem.

O contato das crianças com histórias infantis, em diferentes suportes (digital, impresso et.), torna-se importante ferramenta para que elas adquiram o hábito de ler. É pela leitura que elas começam a descobrir um mundo de conhecimento e informações, para que elas desenvolvam habilidades e, à vista disso, construam seu próprio caminho. A leitura alimenta a imaginação da criança, desencadeia emoções, descobertas, amplia o vocabulário.

Nesse sentido, o planejamento, nas escolas, deveria considerar as mais variadas metodologias para que a criança adquira o hábito e o gosto pela leitura.

Uma dessas metodologias é a Storytelling. É um termo, cuja origem é da língua inglesa, que significa: Story - história; telling - contar. Isso posto, pode-se afirmar que é a arte de contar história com objetivos definidos.

Percebe-se, por conseguinte, um grande desafio para a escola, que é o uso dessas novas metodologias, no processo de ensino/aprendizagem. Frente ao exposto, apresenta-se o problema deste trabalho: Como Storytelling pode ser uma ferramenta 
para o aprendizado ativo, de forma a contribuir, para que a criança, em fase inicial da alfabetização e letramento, aproprie-se dos conhecimentos e ao mesmo tempo desenvolva o gosto pela leitura e escrita?

Quanto ao objetivo geral, analisar como Storytelling pode ser uma ferramenta para o aprendizado ativo, de forma a contribuir, para que a criança, em fase inicial da alfabetização e letramento, aproprie-se dos conhecimentos e ao mesmo tempo desenvolva o gosto pela leitura e escrita.

Como objetivos específicos, seguem: apresentar a relação entre alfabetização e letramento; analisar as metodologias ativas como ferramentas que possam colocar a criança como protagonista do processo; propor uma situação desencadeadora de aprendizagem, utilizando uma história virtual, a partir da Storytelling.

Esta pesquisa tem por finalidade refletir sobre a importância da Storytelling e sua contribuição para o desenvolvimento do processo de alfabetização da criança.

Leal e Galvão (2005, p. 13) apontam que:

[...] o domínio da técnica (relacionar som/grafia, reconhecer letras, codificar, usar o papel, usar o lápis etc.), mas também o domínio do uso nas práticas sociais, as mais variadas, importam em duas aprendizagens distintas, em termos de processos cognitivos e de objetos de conhecimento. Esses processos são distintos, mas indissociáveis, porque as duas aprendizagens se fazem ao mesmo tempo, uma não é pré-requisito da outra.

Sob esse ângulo, as autoras supracitadas afirmam ser possível e fundamental o uso de diversos textos que circulam socialmente, ou seja, o uso de diversos gêneros do discurso usados no cotidiano, para a alfabetização, sem o uso de cartilhas. O que incentiva os alunos, tanto para produzir, quanto para interpretar de textos. Os próprios alunos interagindo entre si, corrigindo seus textos, refazendo etc. "[...] ao professor cumpriria organizar e socializar as informações que os alunos trazem consigo e, progressivamente, criar as situações necessárias em que eles assumam os papéis de leitor e de escritor". (LEAL; GALVÃO, 2005, p. 13). 
Dessa forma, foi selecionada a metodologia ativa, Storytelling, para trabalhar nesta pesquisa e neste período de pandemia, para ser utilizada com o objetivo de oportunizar à criança apropriar-se do conhecimento, construindo de forma ativa.

Em relação à metodologia, esta pesquisa classifica-se como exploratória, com abordagem qualitativa.

Nas seções que seguem, são apresentadas: i) concepções de Alfabetização e letramento; ii) metodologias ativas como estratégia metodológica, no processo de alfabetização; iii) Storytelling como recurso metodológico para o desenvolvimento do processo de aprendizagem: algumas possibilidades; vi) Storytelling e o processo de alfabetização: um relato de uma experiência vivenciada neste período de pandemia do novo coronavírus - COVID-19; e v) Considerações finais.

\section{ALFABETIZAÇÃO E LETRAMENTO}

A alfabetização se dá através do desenvolvimento de atividades que envolvam o aprendizado da criança. Por conseguinte, a criança consegue adquirir a habilidade de leitura, desenvolvendo e capacitando também a criança para a socialização com o meio em que ela vive.

Segundo Kramer (1986, p. 17), a alfabetização “[...] vai além do saber ler e escrever inclui o objetivo de favorecer o desenvolvimento da compreensão e expressão da linguagem".

É importante lembrar que alfabetização e letramento estão juntos na caminhada do ensino-aprendizagem da criança.

Assim, para o processo de alfabetização e letramento, há necessidade que no processo de ensino, o professor centrar-se em gêneros discursivos, dado que são textos que circulam nas mais diversas esferas da sociedade, são práticas sociais.

Traz-se, à vista disso, Soares (2004, p. 14):

RC: 98351

Disponível em: https://www.nucleodoconhecimento.com.br/educacao/storytelling 
[...] a alfabetização se desenvolve no contexto de e por meio de práticas sociais de leitura e de escrita, isto é, através de atividades de letramento, e este, por sua vez, só pode desenvolver-se no contexto da e por meio da aprendizagem das relações fonema-grafema, isto é, em dependência da alfabetização.

A alfabetização pode ser definida como o momento em que a criança adquire novos conhecimentos e desenvolve habilidades e competências para que possa ler e escrever, ou seja, construir significados e produzir sentidos.

Dessa forma, a alfabetização se dá na possibilidade de autonomia da criança ler e escrever, num processo indispensável de apropriação do sistema de escrita. A prática da leitura e da escrita são exercícios no processo de construção da aprendizagem da criança. A alfabetização diz respeito à atribuição e produção de sentido no momento da leitura e da escrita, já o letramento está na prática, no uso que a criança faz em seu dia a dia.

Fernandes (2010, p. 19) assevera que a Educação tem como grandes objetivos: "[...] ensinar a aprender, ensinar a fazer, ensinar a ser, ensinar a conviver em paz, desenvolver a inteligência e ensinar a transformar informações em conhecimento". E, para que esses objetivos sejam alcançados, é preciso o trabalho de alfabetização desenvolver o letramento. Esse autor ainda discorre sobre o que se deve entender por letramento, "[...] como produto da participação em práticas sociais que usam a escrita como sistema simbólico e tecnologia. (FERNANDES, 2010, p. 19).

Pode-se afirmar, então, que o letramento inicia, quando a criança começa a fazer o uso, tanto da leitura, quanto da língua escrita, em ambientes em que vive.

Quando a criança começa a frequentar a escola, depara-se com uma variedade de símbolos e com as possibilidades de combinação que pode haver entre eles, resultando em sentidos diferentes. Isso vai fazer com que se sinta motivada a se apropriar, dessa forma, da leitura e da escrita. Ainda, segundo o Currículo Base do Território Catarinense (CBTC), [...] deve fazer parte do planejamento pedagógico a compreensão da necessidade de aprendizagem do código escrito com o objetivo maior não só da alfabetização por si só, mas da alfabetização para o exercício pleno de cidadania, iniciado ainda nos primeiros anos da escolarização do Ensino Fundamental. (SANTA CATARINA, 2019, p. 148). 
Importa considerar que, para o aprendizado do sistema de escrita alfabética, é necessário que as crianças interajam umas com as outras, utilizando a escrita, construindo sentidos nessas relações,

[...] mediadas pela escrita, quer o professor atue como escriba e leitor, quer as crianças já consigam usar a escrita de modo mais autônomo e menos heterônomo. Importa, pois, que os processos de ensino considerem que o progressivo domínio do sistema de escrita alfabética tem de se dar nos/para os/em favor dos usos sociais da escrita, no âmbito dos gêneros do discurso. (SANTA CATARINA, 2014, p. 123-124).

$E$, consequentemente, é o uso efetivo em práticas sociais pelas crianças, que caracteriza tanto a alfabetização como o letramento.

Para Scholze e Rosing (2007, p. 9):

Ler e escrever não são apenas habilidades estabelecidas em torno da decodificação; muito mais do que isso, saber ler e escrever significa apropriarse das diversas competências relacionadas à cultura orientada pela palavra escrita, para dessa forma atuar nessa cultura e, por decorrência, na sociedade como um todo.

Ainda, conforme os autores acima, "[...] os processos de alfabetização e letramento escolar envolvem, fundamentalmente a apropriação e o uso competente da leitura e da escrita de textos variados com significados e relevância social". (SCHOLZE; ROSING, 2007, p. 38).

As possibilidades de alfabetizar a criança letrando, envolve atividades com práticas que estejam além do contexto escolar da criança, por isso que nem sempre o hábito da leitura e escrita se dá na escola, mediada pelo professor e a criança.

Com o decorrer do tempo, vários métodos de alfabetização já foram utilizados. Sempre no intento de buscar uma metodologia que melhor auxilie as crianças nesse processo, já que, trabalhar de forma incorreta pode levar a consequências graves. Consequentemente, destaca-se a importância da formação continuada para os professores, para a escolha de uma metodologia que melhor se aplique a seus alunos. 
Cita-se Freire (1996, p. 29): "[...] não há ensino sem pesquisa e pesquisa sem ensino. Esses que fazeres se encontram um no corpo do outro. Enquanto ensino continuo buscando, procurando. Ensino porque busco, porque indaguei, porque indago e me indago".

Em vista disso, é necessário que se compreenda como ocorre o processo de aprendizagem da criança, favorecendo, em razão disso, o planejamento das aulas. A sala de aula deve ser um ambiente desafiador, que instigue a criança a superar suas necessidades, devendo ser um ambiente que envolva o aluno, para que possa produzir e interagir a partir da sua realidade.

Convém lembrar que o planejamento deve ser flexível, de fácil intervenção, focando a realidade da criança. O professor é responsável pelo ensino e deve pensar nas atividades de um modo que a criança queira aprender, em razão disso, garantindo uma aprendizagem significativa.

Para Freire (1996, p. 135): "o educador não pode colocar-se na posição ingênua de quem pretende deter todo o saber ou não saber nada, mas deve partir de uma situação mais realista e de uma posição mais humilde".

A prática educativa, no processo de ensino e aprendizagem de crianças no período de alfabetização deve se ater à ludicidade, ter muitas histórias, jogos, músicas, brincadeiras, atividades que agucem a curiosidade, fantasia, a imitação entre outras, que despertem a vontade e o prazer de aprender.

Conforme aponta Rego (1995, p. 118), "[...] uma escola em que as pessoas possam dialogar, duvidar, discutir, questionar e compartilhar saberes. Onde a há espaços para transformações, para diferenças, para o erro, para as contradições, para a colaboração mútua e para a criatividade". 


\section{METODOLOGIAS ATIVAS COMO ESTRATÉGIA METODOLÓGICA NO PROCESSO DE ALFABETIZAÇÃO}

Com o avanço tecnológico e, principalmente, com a internet, novas formas de interação social surgem. Decorre daí o que se tem chamado de "metodologias ativas".

A metodologia ativa, para Bacich e Moran (2018, p. 11), "[...] se caracteriza pela inter-relação entre educação, cultura, sociedade, política e escola, sendo desenvolvida por meio de métodos ativos e criativos, centrados na atividade do aluno com a intenção de propiciar a aprendizagem".

A interação dos conteúdos com novas metodologias ativas é mediada pelo professor, que tem o papel de facilitador, orientando a criança com suas necessidades de aprendizado, possibilitando uma troca e construção de conhecimentos.

Com as mudanças e inovações pelas quais a educação passa, exige-se um olhar mais atento dos professores, em relação às crianças. Por esse motivo, torna-se essencial uma metodologia de ensino capaz de proporcionar à criança uma aprendizagem significativa, para isso, é preciso sempre se reinventar, analisando e arriscando, utilizando, principalmente, as novas formas de interação social, que a cultura digital pode oferecer ao ambiente escolar.

Sobre as diversas estratégias metodológicas que podem ser usadas, no planejamento de aulas, Bacich e Moran (2018, p. 10) consideram ser "[...] um recurso importante, por estimular a reflexão sobre outras questões essenciais, como a relevância da utilização das metodologias ativas para favorecer o engajamento dos alunos e as possibilidades de integração dessas propostas ao currículo".

Com essas mudanças e metodologias, o professor encontra desafios e possibilidades, em novos processos de ensinar e aprender, por meio de práticas 
metodológicas ativas. Portanto, a escola começa a fazer adaptações, organizando seus conteúdos de acordo com essas metodologias ativas.

Segundo Bacich e Moran (2018, p. 3):

Aprendemos também de muitas maneiras, com diversas técnicas e procedimentos, mais ou menos eficazes para conseguir os objetivos desejados. A aprendizagem ativa aumenta a nossa flexibilidade cognitiva, que é a capacidade de alternar e realizar diferentes tarefas, operações mentais ou objetivos e de adaptar-nos a situações inesperadas, superando modelos mentais rígidos e automatismos pouco eficientes.

As metodologias ativas estão voltadas para as escolas e suas práticas pedagógicas, buscando, nessas metodologias, a necessidade de novas transformações e mudanças na educação, considerando que a construção de novos conhecimentos torna a aprendizagem mais significativa, tanto para o professor, quanto para a criança. Com essas metodologias o professor acaba aprendendo junto com a criança.

Ainda, segundo os autores supracitados,

Metodologias ativas são estratégias de ensino centradas na participação efetiva dos estudantes na construção do processo de aprendizagem, de forma flexível, interligada e híbrida. "As metodologias ativas, num mundo conectado e digital, expressam-se por meio de modelos de ensino híbridos, com muitas possíveis combinações. (BACICH; MORAN. 2018, p. 4).

As metodologias ativas exigem uma mudança na postura do professor, transformando o papel da criança de apenas ouvinte, para protagonista da sua trajetória escolar. Nesse sentido, o professor deve pensar em estratégias, que permitam às crianças desenvolverem seus pensamentos críticos e criativos que possibilite a compreensão e a construção de novos conhecimentos, para que o aprender se torna uma aventura permanente no ensino, um progresso crescente e constante na vida escolar da criança.

Importa considerar que o papel do professor é motivar as crianças a irem bem mais além do que já conseguiram sozinhos, estimulando, consequentemente, a sua 
autonomia, a participação, a socialização individual e coletiva, na construção dos conceitos e não em transmitir informações prontas.

A combinação de tantos ambientes e possibilidades de troca, colaboração, com produção e compartilhamento entre pessoas com habilidades diferentes e objetivos comuns traz inúmeras oportunidades de ampliar nossos horizontes, desenhar processos, projetos e descobertas, construir soluções e produtos e mudar valores, atitudes e mentalidades. A combinação equilibrada da flexibilidade da aprendizagem híbrida - blended, misturada - com metodologias ativas - fazendo, refletindo, avaliando e compartilhando facilita a ampliação de nossa percepção, conhecimento e competência em todos os níveis. (BACICH; MORAN. 2018, p. 8).

Nesse sentido, é importante a formação dos professores, conforme expõem Bacich e Moran (2018, p. 199):

É possível apropriar-se de uma nova proposta curricular a partir da atribuição de sentido a ela, a formação de professores é fundamental para a compreensão da necessidade de reorganização do currículo e de suas práticas, bem como para promover mudanças nas concepções sobre o ensino-especialmente quando o novo currículo transforma a estruturação tradicional do conhecimento, passando da ordenação em sequências disciplinares rígidas a uma organização interdisciplinar e baseada em projetos de trabalho, ressignificando práticas previamente estabelecidas.

Para promover mudanças na educação, é preciso ter um outro olhar sobre o processo de ensino, para, a partir daí o trabalho com essas novas metodologias, para o aprendizado das crianças.

\section{STORYTELLING COMO RECURSO METODOLÓGICO PARA O DESENVOLVIMENTO DO PROCESSO DE APRENDIZAGEM}

Diante de novas metodologias para melhorar o ensino e aprendizado, professores vêm tentando inovar, usando a metodologia Storytelling, em seus planos de aula.

A criança aprende, também, por meio de imitações, de narrações. E, em vista disso, acaba criando suas narrativas com algumas particularidades, no meio em que está inserida, mediante a troca mútua de informações entre professores, colegas e objeto de estudo. 
A "contação de história" não é recente, remonta ao período anterior à escrita, quando o homem usava a linguagem oral, usada para narrar acontecimentos, transmitir valores, mitos, passando de geração a geração. Também era usada essa prática para a diversão e o lazer. (FARIA et al., 2017).

Nessa perspectiva, "[...] as informações foram sendo disseminadas inicialmente pela "memória viva" onde a relação entre o dizer e o ouvir se fazia interdependentes em um estado de entrega, intensidade, admiração e conquista desafiando o processar do tempo". (FARIA et al., 2017, p. 31). De acordo com Xavier (2015 p. 5):

Definição pragmática: Storytelling é a tecnarte de elaborar e encadear cenas, dando-lhes um sentido envolvente que capte a atenção das pessoas e enseje a assimilação de uma ideia central. Definição pictórica: Storytelling é a tecnarte de moldar e juntar as peças de um quebra-cabeça formado um quadro memorável. Definição poética: Storytelling é a tecnarte de empilhar tijolos narrativos, construindo monumentos imaginários repletos de significado.

A criança, muitas vezes, fica dispersa em sala e nada chama sua atenção, para isso o professor pode começar a inovar seus métodos, com o uso dessa metodologia, Storytelling, que requer recursos audiovisuais, envolvendo diferentes linguagens, juntamente com a verbal. Com a chegada da era digital, as crianças podem experimentar outras formas de suportes para a leitura, deixando um pouco os livros impressos, e entrar nesse "mundo virtual". À vista disso, o professor, com o avanço das novas tecnologias de comunicação e informação, começa a incrementar suas aulas com essas técnicas.

O professor deve ficar atento ao universo das tecnologias com as quais pode tornar a sala de aula mais criativa e, em vista disso, cativar as crianças, de forma que elas possam interagir mais com esses meios. E esta metodologia, Storytelling, tornar-se um ótimo recurso para o processo de aprendizagem.

Com essas inovações e oportunidades de conhecimentos, contar história torna o principal método para o conhecimento na vida da criança, e, por conseguinte, a Storytelling e suas metodologias claras e técnicas, aplicadas pelos professores, dá oportunidade à criança de construir memórias e imaginações. 
É preciso que o professor mostre para a criança que as narrativas que ela aprende, na escola, não são apenas as melhores histórias, contudo, que podem ser essenciais para seu aprendizado. Na escola, a criança precisa ter voz e vez também.

Palacios e Terezzo (2016, p. XIII) mostram que:

Para se contar uma boa história existe um pressuposto fundamental. Basta seguir esse fundamento que as narrativas ganham vida, as descrições ficam mais coloridas, é quase como um passe de mágica. Isso é tão simples que qualquer pessoa que esteja lendo este livro pode aplicar de uma hora para outra.

Ler e contar histórias trazem benefícios à criança, para o seu desenvolvimento, no seu processo de aprendizagem Por meio da contação de história que o professor começa a dar asas à imaginação e à criatividade da criança e começa a compreender o contexto social em que está inserida, fazendo a troca de informações entre o real e o imaginário.

Antes de qualquer metodologia a ser aplicada em sala de aula, é necessário que o professor prepare um ambiente acolhedor, promovendo o envolvimento das crianças, dando oportunidades para que elas também consigam contar suas histórias.

Para Palacios e Terenzzo (2016, p. 101):

Mais do que despertar a imaginação, uma boa história é capaz de transmitir pensamentos de forma quase telepática. As narrativas permitem que o autor e todos aqueles que estão atentos à narrativa compartilhem pensamentos e sonhos. Se por um lado a sociedade está realista e racional, por outro ela implora por mais imaginação. Aqueles que atendem a esse pedido são muito bem recompensados.

A metodologia Storytelling é uma ferramenta que pode ajudar o professor em seu planejamento, auxiliando a criança no seu aprendizado, posto que se torna uma maneira de fazer com que os conceitos a serem trabalhados sejam internalizados pela criança de uma maneira mais lúdica. 
De acordo com Palacios e Terenzzo (2016, p. 103):

\begin{abstract}
Storytelling é uma simulação de uma realidade. Ao cativar a atenção, a narrativa provoca uma imersão que chega ao nível sensorial. Por ter uma estrutura aberta e simbólica, de conteúdos interpretáveis, é muito fácil para uma pessoa encaixar-se em uma história. Este processo psicológico é chamado de "projeção". A pessoa que está atenta se projeta dentro de um personagem, algumas vezes torcendo por ele e outras se colocando no lugar dele. Sempre que estamos atentos a uma história compartilhamos o olhar e os sentimentos dos personagens. Para o bem ou para o mal. Vibramos juntos, mas também choramos em sintonia. Quando algo é muito importante para o protagonista, passa a ser muito importante para quem está atendo.
\end{abstract}

Com essas novas tecnologias, o suporte digital vem apresentando novas possibilidades e maneiras diferentes de ensino, permitindo, portanto, que o professor construa com a criança novos caminhos de leitura e aprendizado, criando, também, novas formas de se relacionar com o conhecimento digital.

\title{
5. STORYTELLING E O PROCESSO DE ALFABETIZAÇÃO: RELATO DE UMA EXPERIÊNCIA VIVENCIADA NESSE PERÍODO DE PANDEMIA DO NOVO CORONAVÍRUS - COVID-19
}

A pesquisa foi realizada no Colégio X, pela professora Janaína Flicidade, com seus próprios alunos, através de um plano de aula remoto, devido à pandemia.

O plano de intervenção teve como título "Storytelling: contribuições para desenvolver o gosto pela leitura e escrita no processo de ensino aprendizagem. Já o plano de aula, para aplicação teve o tema "Motivar a leitura e a escrita na alfabetização". Foi desenvolvido com uma turma de $1^{\circ}$ ano do ensino fundamental.

Como material de apoio, foram utilizadas as apostilas referentes ao método de ensino adotado pelo colégio, como: produção textual, leitura / escrita, português, matemática, natureza / sociedade e livros clássicos infantis.

O livro utilizado foi "Os Três Porquinhos", que acompanha o kit escolar das crianças. Ler palavras em pequenos textos, apoiando-se na narrativa da história, preparando a atenção das crianças na pronúncia das palavras e pregando os olhinhos delas nas 
imagens do livrinho, facilita a aprendizagem como um todo, dado que, capta a atenção das crianças, desperta o conhecimento prévio e facilita a escrita espontânea da criança.

$\mathrm{O}$ ato de contar história aguça a imaginação e a criatividade. As imagens ajudam muito a reconhecer o significado dos símbolos, e o adulto ao ler em voz alta, dando ênfase à entonação das palavras, pronunciando o som das letras e sílabas, faz com que a criança compreenda a história lida, codificando e decodificando na hora da escrita, facilitando identificar os erros escritos através da fala, estabelecendo, por conseguinte, relação entre fonema / grafema.

O plano para essa aula remota teve como objetivo despertar o interesse das crianças pela leitura e escrita, em fase inicial de alfabetização e letramento.

Os objetivos específicos foram baseados nas habilidades e competências trabalhadas, tais como: a) perceber qual a função da leitura e escrita, no processo de ensino aprendizagem; b) reconhecer a relação entre alfabetização e letramento; c) estimular a criatividade espontânea, dando asas à imaginação; d) orientar sempre os pais, para uma melhor pronúncia das palavras e atenção das crianças, na escuta, porque falar com mais desenvoltura, devagar, sem medo e com clareza facilita o entendimento da criança, em relação ao som das silabas nas palavras; e e) pedir aos pais que ampliassem o vocabulário de seus filhos por meio do diálogo simples e claro, dando oportunidade para a criança trocar ideias, visualizar as imagens e as palavras, entendendo, portanto, como será sua escrita futura.

Considerando que as escolas estão fechadas, com aulas presenciais suspensas, devido à pandemia COVID-19 / corona vírus, foi feita uma adaptação, na aplicação do plano de aula, com o uso das tecnologias em aula remota. Foi entrado em contato com a direção da escola, pedindo autorização na aplicação da metodologia que visava a confecção de uma mascote, para ser escolhido como representante visual, como companhia da criança durante as leituras. Em razão disso, ela mesma sentiria prazer de ler ao recontar a história para a mascote, já sabendo ler ou seguindo as imagens. 
O caminho utilizado para aplicação do plano de aula e feedback das crianças foram as aulas on-line pelo Zoom, no qual foram feitas as conversar, para alinhar a intervenção. A gravação de explicação dos conteúdos, foi disponibilizado no portal do colégio, no qual, os pais e crianças têm acesso por senha. E para conversas, foi utilizado o celular pelo WhatsApp com mensagens ou chamada de vídeo, muitos pais solicitavam ainda Xerox algo digitado, para entender melhor, como um cronograma.

Com esse planejamento, a intenção visava verificar se a criança tem conhecimento de letra, silaba, palavra e números. Ao recontar a história para a mascote, observouse na fala da criança qual o personagem a criança gostou mais, menos; a parte da história que gostou, não gostou; o que mudaria na história; se achou engraçado quando; se ela faz comentário com relação aos dias atuais etc. Toda essa construção de pensamento foi mediante diálogos com as crianças pelo Zoom, a conversa com a mascote que as crianças realizaram em casa enriqueceu a aprendizagem e deu asas à imaginação.

Para Moran (2012, p. 43):

O conhecimento não se impõe, constrói-se. O grande desafio da educação é ajudar a desenvolver durante anos, no aluno, a curiosidade, a motivação, o gosto por aprender. O gosto vem do desejo de conhecer e da facilidade em fazê-lo. A facilidade depende do domínio técnico da litura, da escrita, da capacidade de análise, comparação, síntese, organização de ideias e sua aplicação.

Pensando no ato de ler, o letramento tem início quando a criança começa a falar e se expressar, no ambiente em que vive, e conviver com pessoas que fazem o uso da língua escrita, como o papai, a mamãe e os irmãos. Dessa forma, a criança vai conhecendo e reconhecendo a prática de leitura e de escrita. Sem se dar conta ela vai adquirindo conhecimento verbal, através da sua curiosidade, vai tendo contado com a escrita.

E a alfabetização surge quando a criança começa a ir para a escola ou instituição de ensino, lidando com diversos materiais de aprendizagem e utilizando a sua bagagem 
de conhecimento pessoal, a criança cria o hábito e a prática pela língua escrita, motivada pela família e pelo professor, ou até mesmo um adulto de sua afinidade.

Conforme o Currículo Base do Território Catarinense (SANTA CATARINA, 2019, p. 148):

As crianças, gradativamente ampliam seus repertórios linguísticos e culturais por meio de diferentes linguagens: oralidade, gestos, desenhos, brincadeiras, pinturas, esculturas, entre outras. Assim sendo, é por meio das diferentes linguagens que as crianças se comunicam e expressam seu pensamento; quanto mais forem oportunizadas em que elas possam viver intensamente essas experiências, mais se desenvolvem integralmente. Isso implica considerar que, ao ingressar no ensino fundamental, as crianças de seis anos necessitam se expressar por meio de múltiplas linguagens, e que as brincadeiras, a imaginação e a fantasia constituem seus modos de ser e viver no mundo.

Para trabalhar a leitura foi necessário a interação tecnológica dos conteúdos com novas metodologias ativas que foi mediada pelo professor, que facilitou e orientou a criança a compreender melhor certos assuntos. O professor dá um caminho para possibilitar uma troca e construção de conhecimentos, não entrega a resposta em momento algum e sim orienta e desenvolve o conhecimento a partir de uma situação desencadeadora de aprendizagem. O professor deve utilizar um planejamento flexivo e com base em uma metodologia adequada aos conteúdos, como por exemplo, a Storytelling, que tem se mostrado apropriada, para se ter sucesso na aprendizagem.

Conforme pode ser visto em Bacich e Moran (2018, p. 11):

As tecnologias facilitam a aprendizagem colaborativa, entre colegas próximos e distantes. É cada vez mais importante a comunicação ente pares, entre iguais, dos alunos entre si, trocando informações, participando de atividades em conjunto, resolvendo desafios, realizando projetos, avaliando-se mutuamente. Fora da escola acontece o mesmo, na comunicação entre grupos, nas redes sociais, que compartilham interesses, vivencias, pesquisas, aprendizagens.

Convém destacar que, ao contar uma história, a criança tem a sua atenção voltada para o que ouve, é o momento de, junto a isso, usar as tecnologias que estão 
disponíveis em favor da educação. O professor deve usar maneiras de cativar a atenção das crianças de forma lúdica e prazerosa.

Para Palacios e Terenzzo (2016 p. 14):

Se você está consumindo alguma coisa você está atento. Você está atento quando está o cinema ou lendo um livro; você larga tudo o que está fazendo e pega o livro com as duas mãos e você até desliga o celular quando está no cinema...

...Atento é aquele que presta atenção, que está sintonizado, que não dorme, que está absorvido, mergulhado, extasiado. Está imerso.

Deve-se levar em conta como desenvolver as habilidades e competências nas crianças, para a leitura e escrita por meio do uso de textos. Ao ler e analisar os registros das crianças, o professor deve observar se o que a criança escreveu tem lógica ou precisa ser trabalhada novamente a história até que ela entenda o som das letras, possibilitando a alfabetização e o letramento de forma interdependente.

De acordo com Soares (2020, p. 33), "Letrar desenvolvendo habilidades de leitura, interpretação e produção de texto. Alfabetizar situando no texto a aprendizagem do sistema alfabético de que os alunos precisam apropriar-se para que se tornem capazes, eles também, de ler e escrever texto".

Não há gosto pela leitura sem que o professor facilite, motive as crianças pois a motivação pode desenvolver a criatividade, a liberdade e o conhecimento. $O$ professor deve valorizar o que a criança diz, uma vez que ela é a grande protagonista dessa etapa. A leitura é uma prática importantíssima que ajuda na formação cultural e cidadã das crianças.

A leitura se torna importante para a criança, quando ela cria o hábito e começa a descobrir um mundo de conhecimento e informações, dando oportunidades de a criança adquirir habilidades para que ela possa construir seu próprio caminho. Nesse momento, os professores como incentivadores fazem um grande trabalho. 
No início da alfabetização, é preciso fazer com que a criança compreenda primeiro a representação do som das letras e silabas, via oralidade, e transforme em escrita. Para isso, a narrativa da história deve ser feita cautelosamente, para facilitar essa compreensão, na hora da atividade. Alguns erros das crianças são justificados pela forma que elas ouvem o som dos fonemas, a fala influencia muito na escrita, é importantíssimo a pronúncia das palavras da criança, pois os fonemas vocálicos criam dificuldades ortográficas para crianças, em fase de alfabetização, por exemplo, a representação da nasalidade é um dos aspectos mais difíceis também, por isso o cuidado com o som dos fonemas é importantíssimo.

De acordo com Soares (2020, p. 174):

As regras ortográficas vão sendo aprendidas ao longo do processo de alfabetização e de acordo com as dificuldades ou curiosidades que vão sendo apresentadas pelas crianças. Mesmo considerando o crescimento progressivo da complexidade das relações fonema-grafema - das relações regulares aos irregulares contextuais, até irregulares -, a criança pode aprender simultaneamente ao longo do processo de alfabetização várias dessas relações, dependendo de suas dúvidas, de suas demandas e das oportunidades que surjam.

Formar leitores ainda é um desafio, para professores, então para despertar o interesse dos alunos, mesmo nesse período de pandemia, longe das escolas, só utilizando os recursos digitais. Para isso a ideia de rodas de leitura pode ampliar o repertório do leitor e o aprofundamento da leitura autônoma. Por meio da mediação do professor com a família, buscam-se novas interações com o livro de maneira prazerosa, entendendo as histórias como fonte de múltiplas informações e de entretenimento.

Por isso, tende-se a compartilhar experiências pelo prazer da leitura, pela criatividade, pelo escutar o outro, pela oralidade, priorizando a leitura colaborativa e compartilhada. O professor necessita buscar um ambiente alfabetizador, em que possa pensar em métodos que permitam aos alunos desenvolver formas de pensamentos que Ihes possibilitem a apropriação, a compreensão e a produção de novos conhecimentos. Mas nesse período de pandemia, foi feita a leitura coletiva com as crianças (on-line) e individual reflexiva com família (pais, criança e mascote). 
Tratar da alfabetização e do letramento, nesse período, será como montar um quebra-cabeça, em que ensinar terá seus desafios, dificuldades, pois ninguém é igual e aprende-se de diferentes formas.

Soares (2020, p. 27) afirma:

As duas peças do quebra-cabeça, uma representando alfabetização e a outra representando o letramento, ... Como um quebra-cabeça, cada peça só ganha sentido quando associada a outra peça que a contempla. Também alfabetização e letramento são processos interdependentes. Como um quebra-cabeça as peças são diferentes, com cada peça tendo uma forma que se encaixa à forma específica de outra. Também os processos de alfabetização e letramento são diferentes, envolvendo, cada um, conhecimento, habilidades e competências especificas, consequentemente, procedimentos diferenciados de ensino.

Como vem sendo dito, foca-se a alfabetização sempre no contexto do letramento para uma melhor apropriação da leitura e escrita pela criança.

Segundo Soares (2020, p. 193):

Assim, na leitura, o processo parte dos grafemas para os fonemas, isto é, a criança precisa identificar nos grafemas os fonemas que eles representam para chegar à palavra; na escrita, ao contrário, o processo parte dos fonemas para os grafemas, isto é, a criança precisa identificar os fonemas da palavra que deseja escrever e representá-los por grafema.

Conforme já mencionado, foi criado uma mascote para que a criança não se sentisse sozinha. Seria uma mascote para a turma toda, durante o ano, ir se revezando, cada dia um leva para casa, com uma bolsa contendo livrinhos. Todavia devido à pandemia, cada um criou o seu que foi seu companheiro para todas as histórias trabalhadas, durante as aulas remotas, no ano 2020, no colégio. E as histórias que tivessem em casa também poderiam ser lidas. Essa ideia é para as crianças criarem relação afetiva e prazerosa com os livros, por meio da mascote. Nosso ouvinte e companheiro viajante.

Foi também criado um ursinho com toalha de rosto ou de boca e dado um nome, para que ele acompanhasse a criança, a uma viajem em busca do conhecimento. Usou-se o material didático como apoio, sempre encaixando os conteúdos com a 
análise das histórias clássicas vão sendo estudadas, para essa pesquisa, foi a história dos Três Porquinhos.

\section{EPISODIO 1: criação da mascote}

Foi gravado uma videoaula, para o portal da escola, mostrando os materiais necessários para a montagem da mascote e o passo a passo da sua criação. No foi falado sobre um momento de amizade e aproximação, contou-se para a turma que "ele", a mascote, é muito esperto, adora viajar e ouvir histórias. Segundo a leitura do livro storytelling de Placios e Terenzzo (2016. p. 61) "[...] não basta a história ser fabulosa e o propósito ser épico, também é igualmente fundamental a forma como se organiza e transmite as informações da história".

Pode ser visto, na Figura 1, a confecção da mascote, conforme segue abaixo.

Figura 1 - Confecção da mascote.
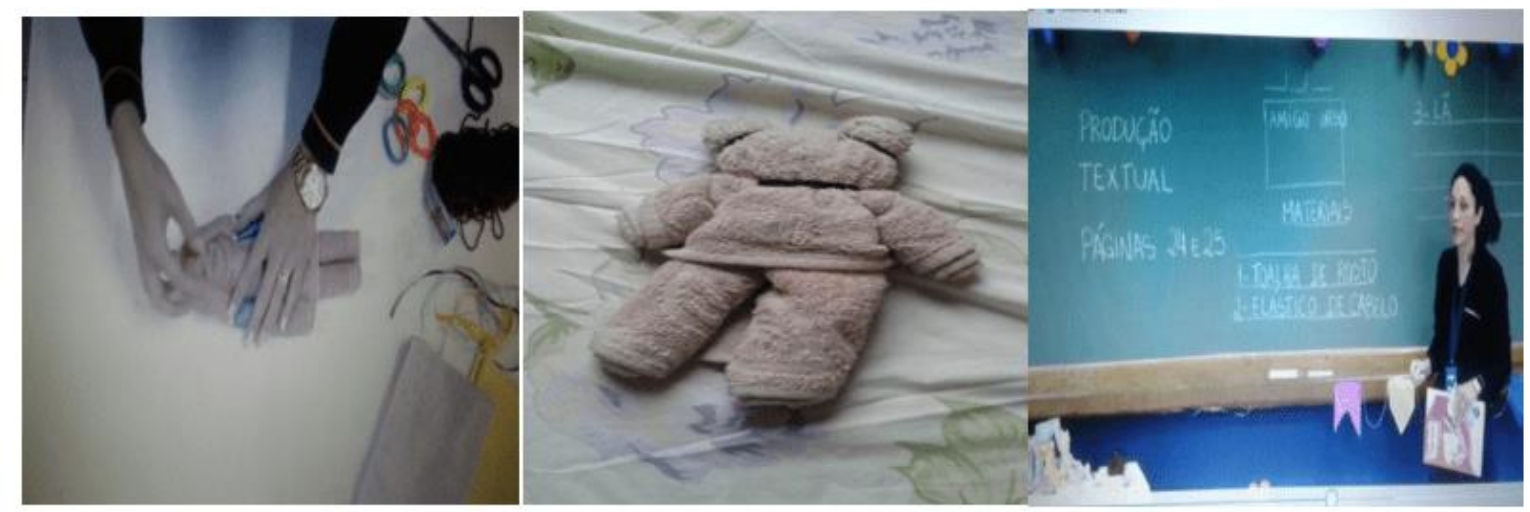

Fonte: arquivo pessoal.

Incentivou-se as crianças na criação de um simples urso que serviria de companhia para as leituras, para as viagens e troca de ideias. Foi dito para as crianças darem preferência à leitura dos três porquinhos, pois é a que estavam estudando, mas que depois, ouviriam outras histórias.

Para Soares (2020 p. 213), 
[...] a escolha pode também partir de um texto que esteja, em determinado momento, presente no contexto social ou escolar, e que se caracterize como de um determinado gênero que deve fazer parte do repertório da criança no ciclo de alfabetização e letramento, por sua frequência na escola e nos meios de comunicação pública.

Pediu-se que uma vez por semana e no mesmo horário, fosse o momento da leitura, para que as crianças criassem o hábito (poderia ser antes de dormir, com a ajuda de um adulto). Em virtude disso, poderia viver toda semana uma aventura com o amigo. Também foi lembrado de usar a mascote nas aulas como companheiro das histórias clássicas.

Ao final da videoaula, foi explicado para usarem a apostila de produção textual e escrever os materiais que utilizaram na montagem de seu urso. Produziu-se no quadro o texto da professora para elas terem como base, pediu-se para usarem a criatividade, e que poderiam colocar mais coisas, no urso, e escrever, se preferissem.

A partir desse momento, as crianças vivenciaram um momento lúdico em família, pois o mundo muda e as aulas também. Neste momento de pandemia, os pais são parceiros inseparáveis dos professores. As transformações sociais exigem que se tome decisões, realizadoras de grandes desafios, porém agora necessita-se de ajuda. Obtêm-se os relatos através do adulto responsável pela criança. Dessa forma, professores e pais assumem um papel social muito mais complexo e relevante que é o de despertar interesses nas crianças que necessitam de saberes úteis mediante uma metodologia prática e eficiente, destacando a necessidade de centrar o ensino e a aprendizagem, no desenvolvimento por competências e por habilidades.

Sobre esse episódio, muitos disseram: isso é fantástico.

EPISODIO 2: Retorno da criação da mascote

Recebe-se pelo WhatsApp a imagem da apostila das crianças e a foto da mascote, como elas conseguiram criar e usar a criatividade. 
Abaixo, apresenta-se a Figura 2 que traz o texto da criança $S$, com a lista de materiais que ela utilizou para a confecção da mascote bem como a imagem das mascotes.

Figura 2 - Texto de uma criança com sua mascote.

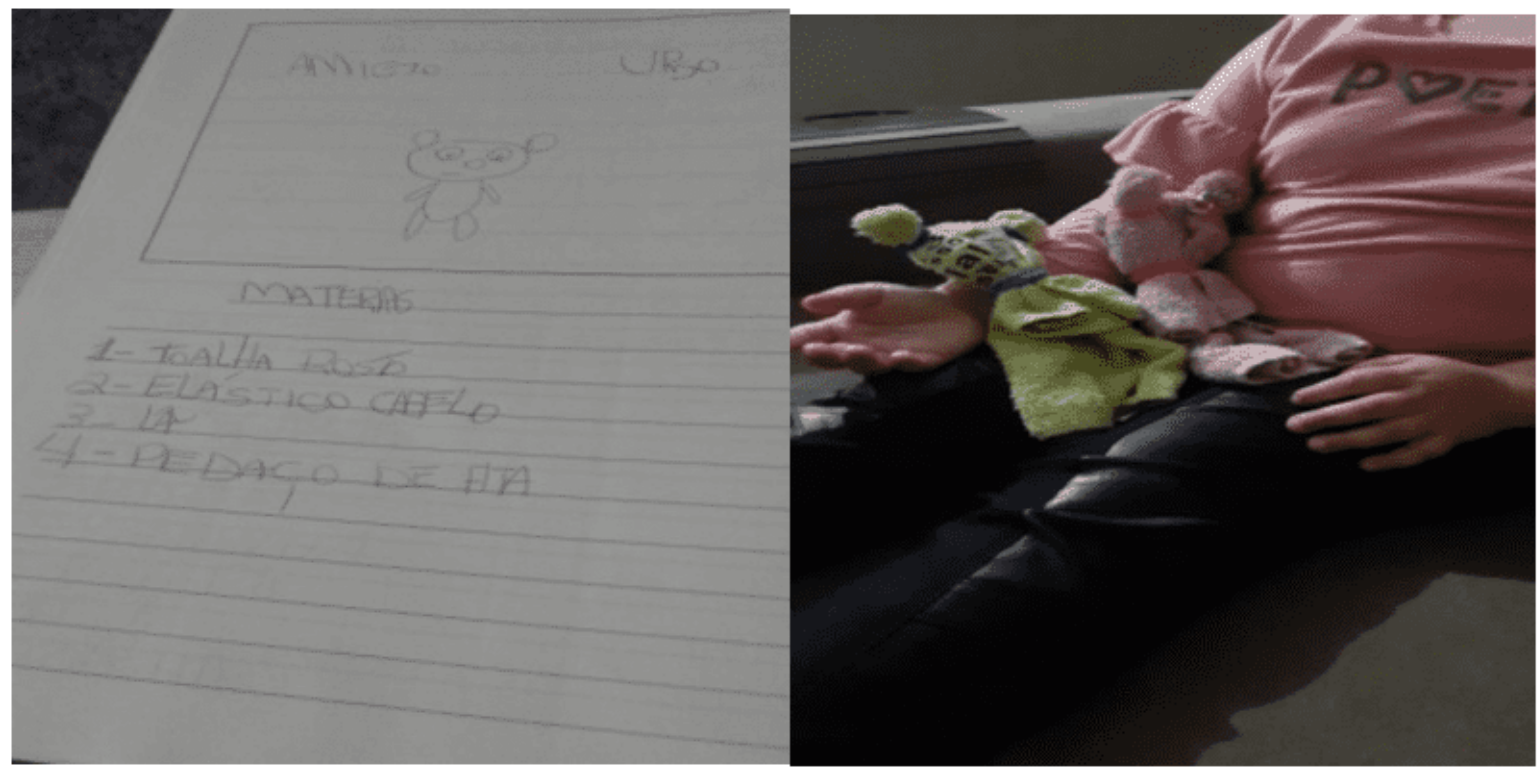

Fonte: arquivo pessoal.

Aluna S: profe fiz dois amigo urso com a ajuda da mãe, pois só um ia fica triste, assim um faz companhia para o outro e nós juntos formamos três, igual aos três porquinhos. Kkkkk. Profe a rosa é a Clarinha menina, o verde é o Dudu menino. Fiz até um para a minha vovó, pois ela está sozinha e serve de companhia. Kkkkk

Na Figura 3, pode ser visualizada a lista de material para a confecção da mascote pela criança $D$ e a sua imagem. 
Figura 3 - Texto de uma criança com sua mascote

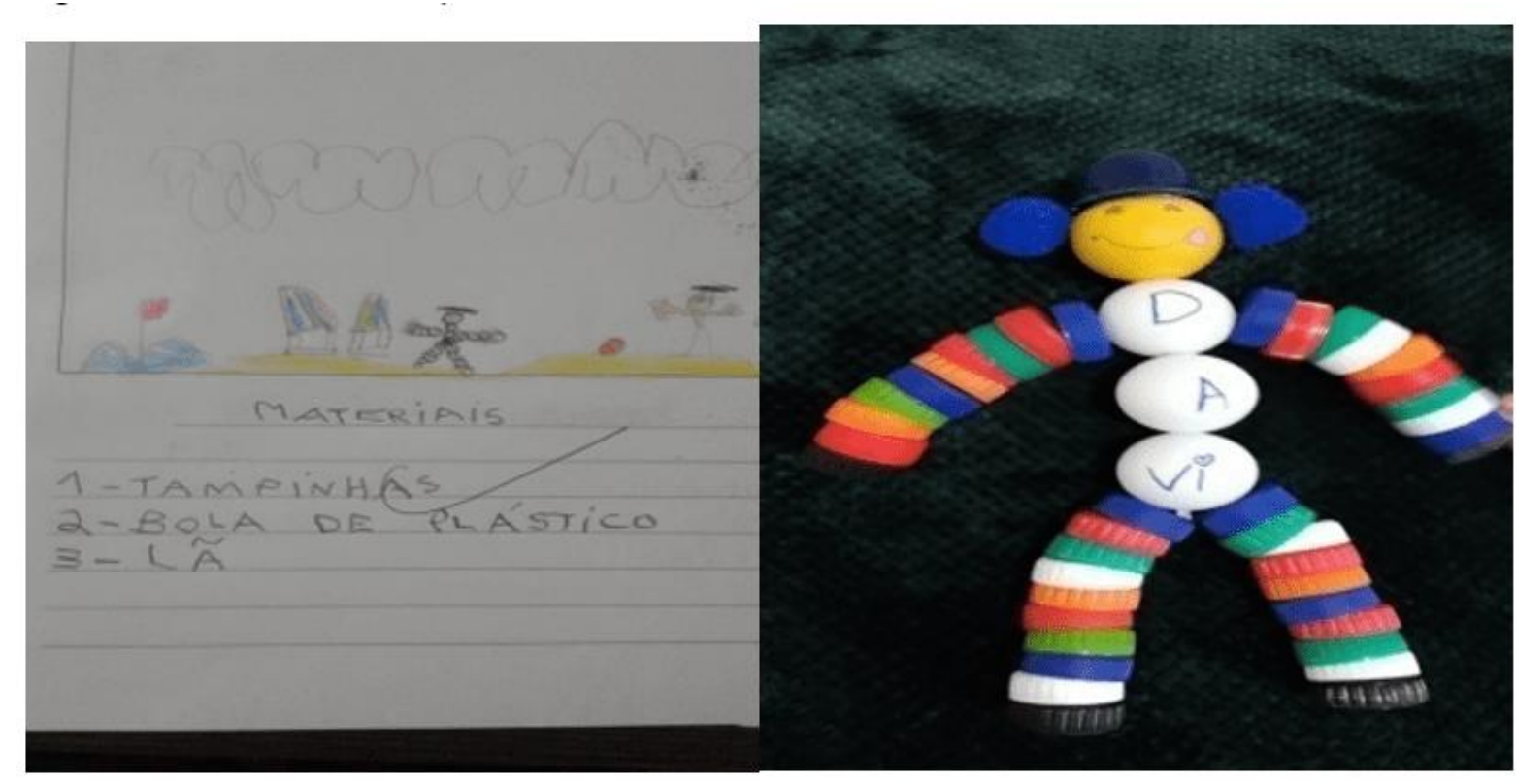

Fonte: arquivo pessoal.

Aluno D: profe como você pediu para usar criatividade, papai teve a ideia de fazermos com tampinhas que eu junto. Olha que legal! O nome dele é Tampinha

Percebe-se o envolvimento dos pais nas atividades das crianças, fundamental não só nesse momento de pandemia, como também para o processo de aprendizagem.

EPISODIO 3: Cantinho da leitura em casa

Gravou-se uma videoaula, tecendo comentários sobre a importância de se ter um local para a leitura. Mesmo não estando na escola, em suas casas poderiam ter um local para ler; a proposta foi incentivar as crianças e as famílias a terem seus próprios "cantinhos de leitura" em casa, ou momentos rotina, horários adequados.

Foi proposto, junto com a família, para que cada um preparasse o seu cantinho de leitura, de maneira que ficasse caprichado e acolhedor, para que a criança gostasse tanto de participar da arrumação do cantinho, como também que ficasse nesse espaço. 
Pediu-se para os pais que valorizassem o momento da arrumação do local, em virtude que se faria com a ajuda delas, um cantinho também na sala de aula, na escola, cada detalhe. Na sala, fez-se um cantinho e dali foi contado uma história, para motivá-las a fazerem os seus. Contou-se a história: Os três gatinhos, livro disponível na biblioteca da escola. As crianças aprendem a ler e, ao mesmo tempo, estão lendo, por meio da mediação do professor, que lhes empresta os olhos e a voz. Nesse momento, o professor conta com a ajuda dos pais, na mediação da leitura. O professor orienta o encontro da criança com o livro, com a história, promovendo a interação prazerosa da criança com a leitura.

Para Soares (2020, p. 232):

A mediação literária deve ocorrer em ambiente que se diferencie tanto quanto possível da sala de aula, ainda que ocorra nela mesma com as crianças sentadas em círculo para a "hora da literatura", ou na biblioteca, em que as crianças estarão na "casa dos livros", rodeadas deles, também sentadas em círculo para acompanhar a leitura, que deverá ser cuidadosamente preparada pela professora.

Dessa maneira, a atenção passa a ser a montagem do lugar, sem perceberem a mobilização de uma série de conhecimentos e interação um com o outro, de como seria, na escola.

Na Figura 4, apresenta-se como foi o momento de contação de história a partir do cantinho elaborado pela professora. 
Figura 4 - Contando a história: "Os três gatinhos".

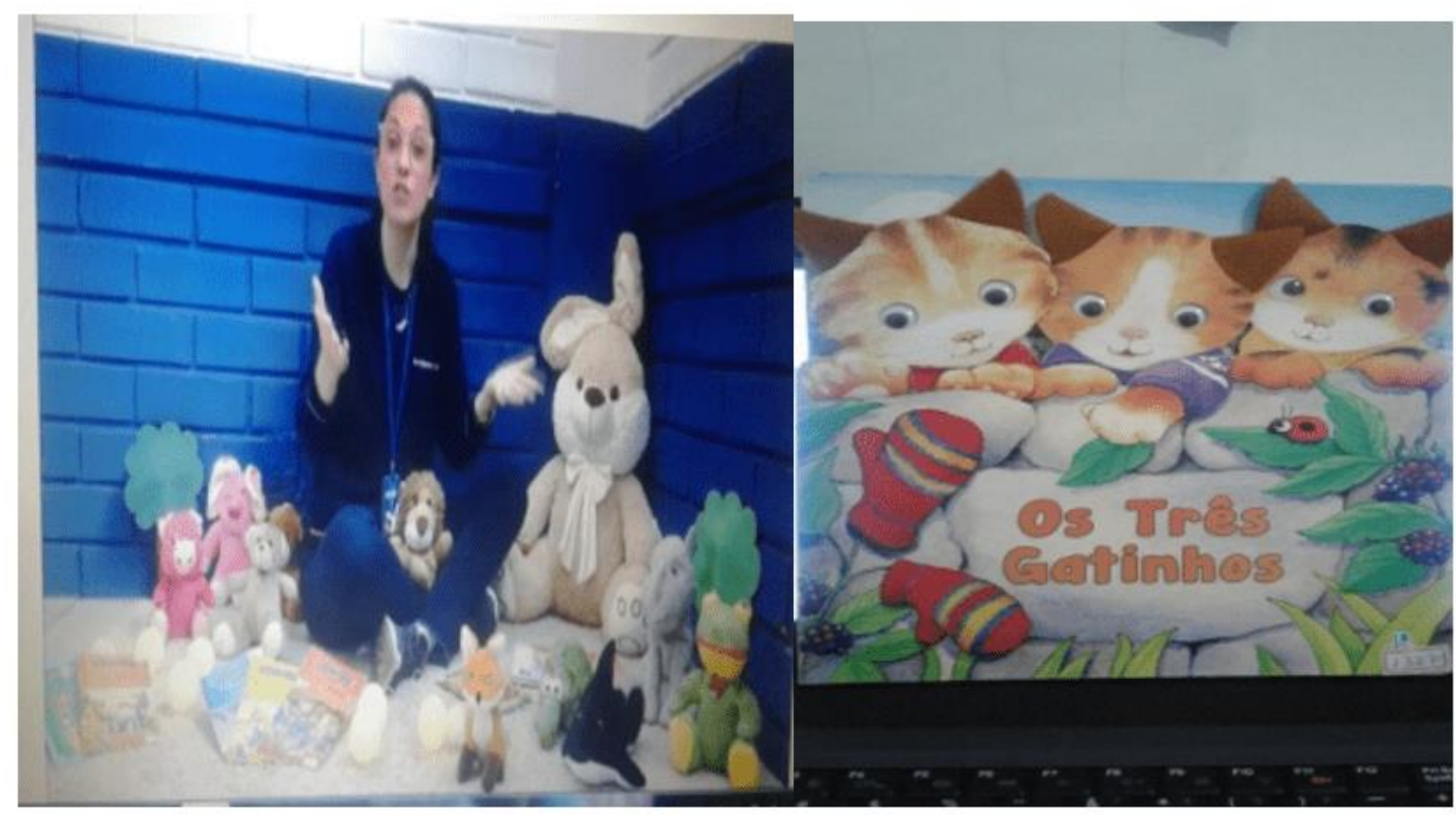

Fonte: arquivo pessoal.

O mais importante é trabalhar o processo de desenvolvimento da leitura, a apropriação e a construção de sentido na troca de experiência. Em outras palavras, a socialização da criação do local da leitura terá significados, para depois fazer uso do material linguístico-textual e obter conhecimento aprofundado com a família.

Esse ambiente foi proposto às crianças, para que, nessa interação, fosse estabelecido uma relação de proximidade entre professor e pais, pais e criança, criança e leitura e escrita.

EPISODIO 4: Retorno sobre o cantinho da leitura

As crianças enviaram fotos do caninho que fizeram em suas casas, para leitura com a mascote e com os pais. 
Figura 5 - Construindo o "cantinho da leitura".

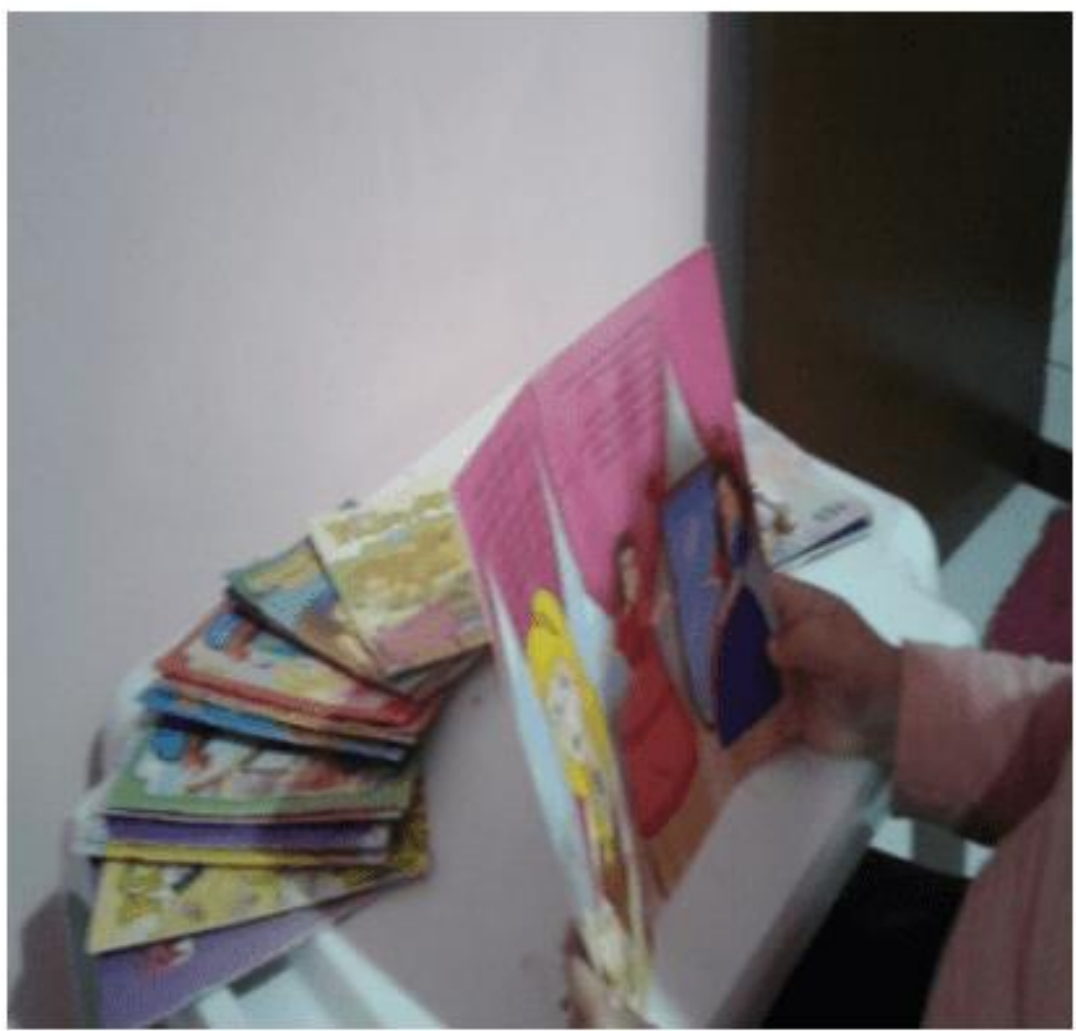

Fonte: arquivo pessoal.

Aluna S: profe no meu quarto tem uma mesinha onde ficam os meus livrinhos, a mãe senta no tapetinho do lado para ler comigo.

A Figura 5 mostra o cantinho da aluna $\mathrm{S}$, o seu envolvimento com as leituras. Importante destacar novamente a significância dos pais para esse processo.

EPISODIO 5: Narrativa os três porquinhos

Foi gravado uma videoaula aula, para o portal da escola, com a narrativa da história a ser trabalhada no momento com a turma. Uma colega de trabalho foi narrando, enquanto a professora dramatizava a história, desenhando em folha de ofício e usando bichos de pelúcia, para ilustrar a história.

Mostrou-se o livro para ser lido em casa, com a ajuda de um adulto (clássicos infantis que fazem parte do material didático). Recomendou-se que prestassem 
atenção na narrativa da professora e, na forma que o adulto iria ler, quando ouvissem uma palavra conhecida olhassem a escrita. Ao final da videoaula foi explicado, para que usassem a apostila de leitura e escrita, em que pede para desenhar e escrever o que aconteceu no final da história, e o que mais chamou sua atenção.

Conforme detalhou-se esse momento, pode parecer uma aula qualquer, porém é um trabalho técnico da aquisição das competências leitoras, certamente exigiu um esforço maior e mental dos pais, no entanto, além do prazer pela leitura, há aspectos emocionais que envolvem a leitura, como o exemplo do adulto, o gosto e hábito do adulto, isso pode despertar o encantamento da criança.

Figura 6 - llustração da história de cabeça para baixo

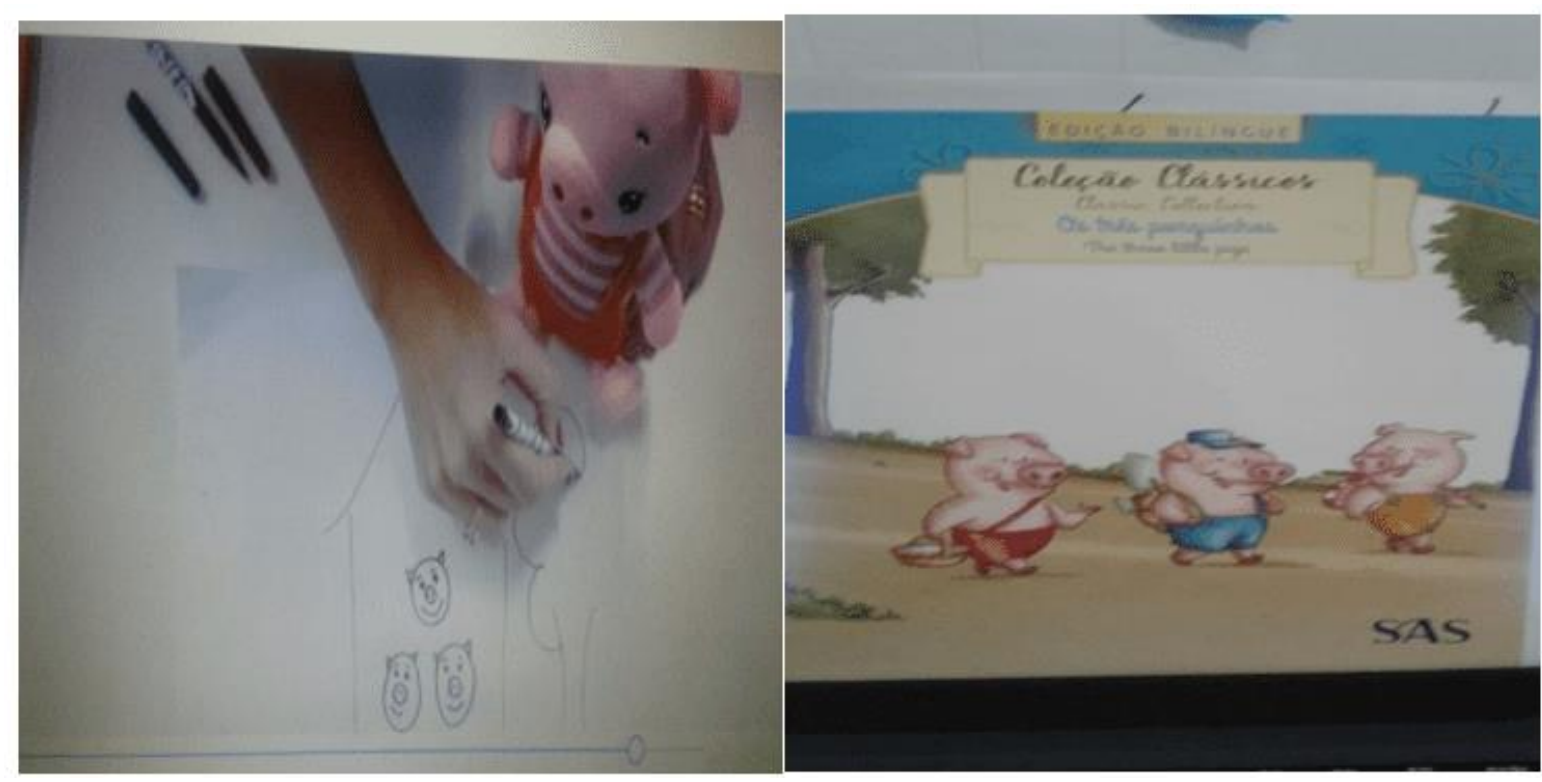

Fonte: arquivo pessoal.

Aluna S: profe você é muito esperta desenhou de cabeça para baixo. Que legal!

Sem se dar conta no momento da gravação da videoaula, os desenhos referentes à história contada saíram de cabeça para baixo, por causa do reflexo de uma sombra no papel. As crianças notaram esse detalhe, na verdade os espertos são eles, super atenciosos e detalhistas, muito bem observado. 
EPISODIO 6: Atividades de leitura e escrita

As crianças enviaram foto pelo WhatsApp da apostila leitura e escrita, assim que realizaram as atividades das páginas solicitadas.

Figura 7 - Atividades realizadas pelas crianças.

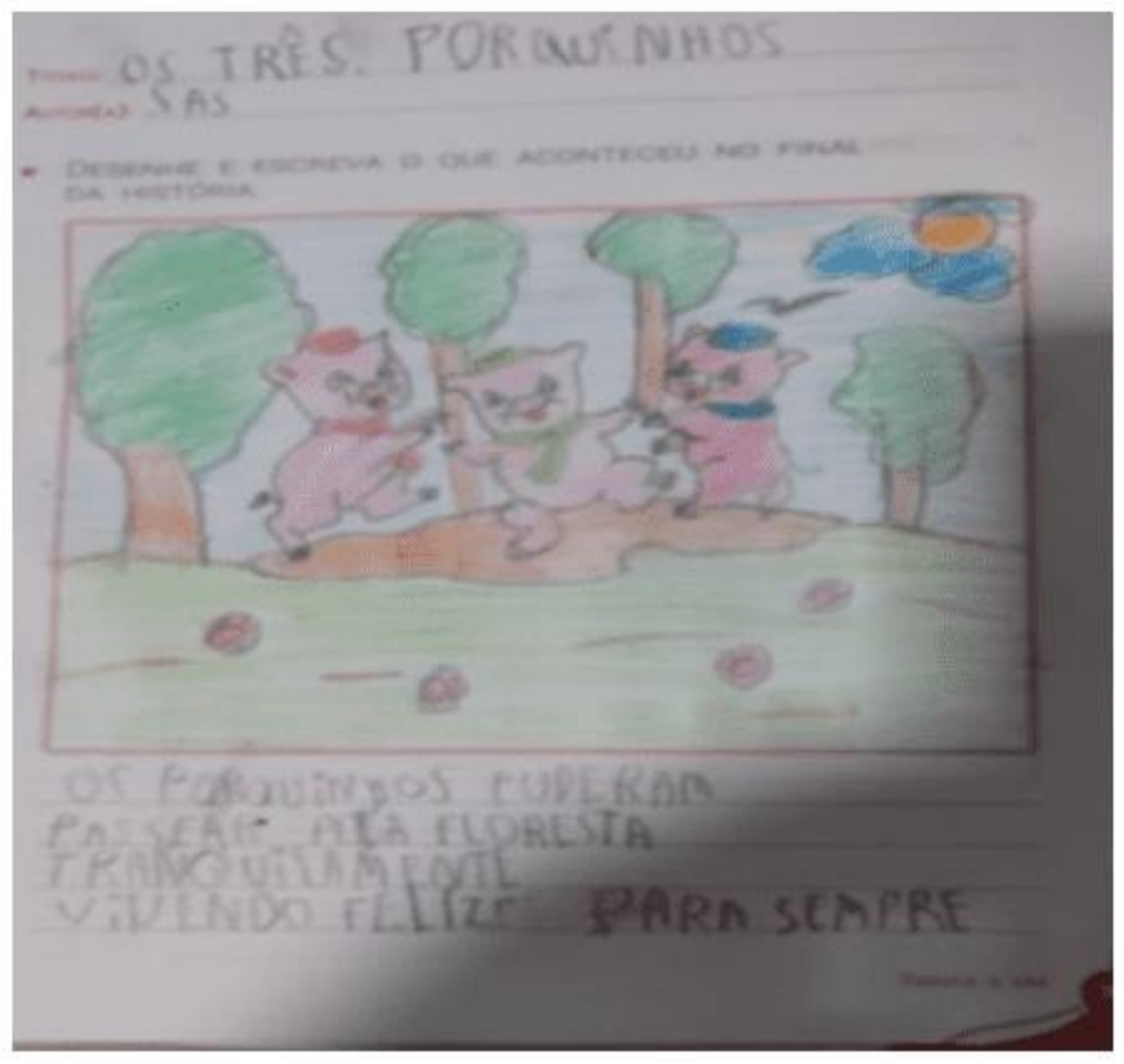

Fonte: arquivo pessoal.

Aluno D: profe fiz a página da apostila com muito carinho, minha mãe disse para caprichar que você gosta de colorido. Coisa linda! 
Figura 8 - Atividades realizadas pelas crianças.

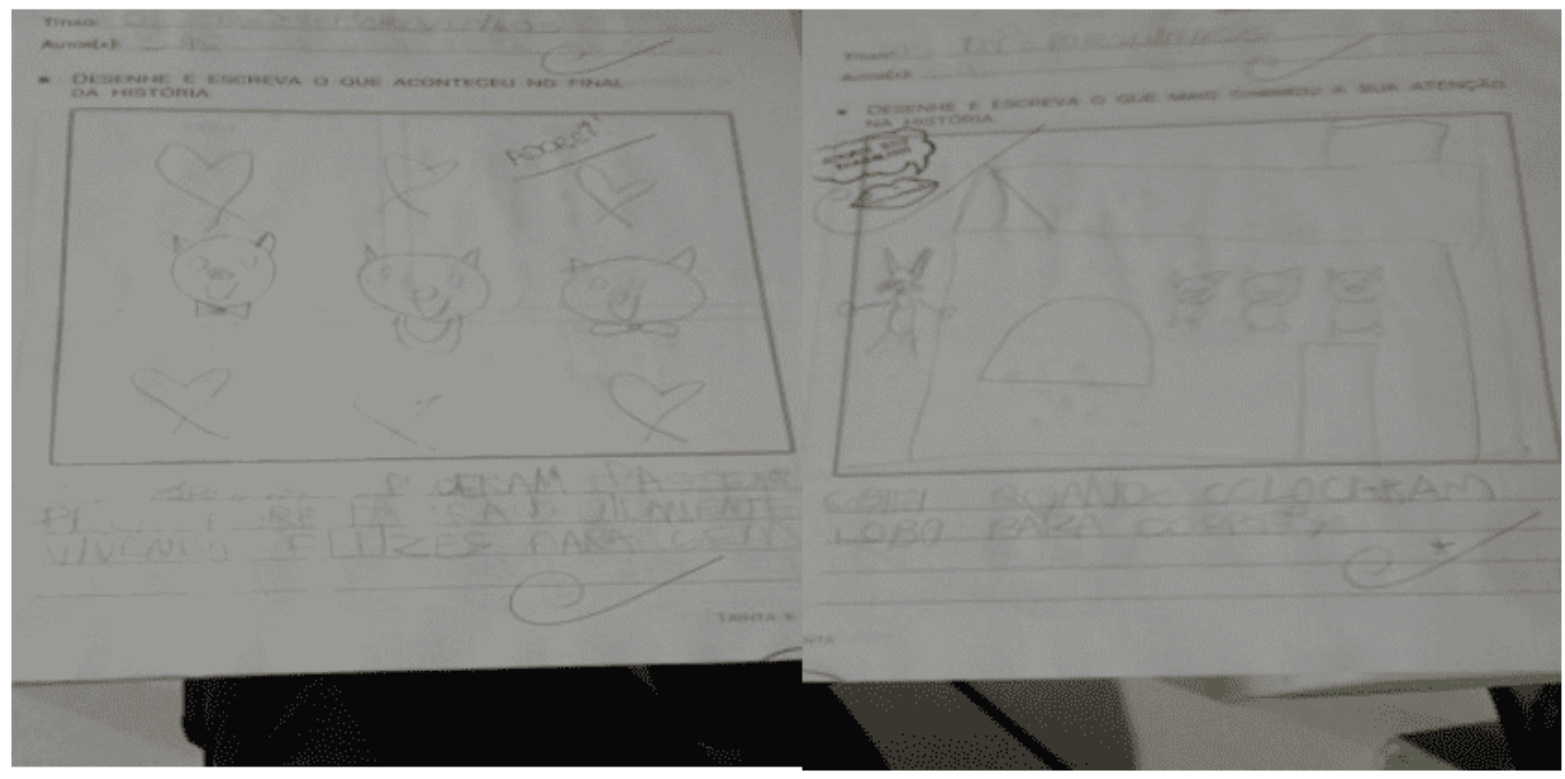

Fonte: arquivo pessoal.

Aluna S:profe fiz as duas páginas, mais a que eu mais gostei foi a que chamou atenção, quando os porquinhos colocaram o lobo pra correr, kkkk.

Nas Figuras 7 e 8, podem ser visualizadas a produção das atividades pelas crianças assim como as ilustrações que fizeram em relação à história contada. Ainda, pelo próprio diálogo estabelecido pelo WhatsApp, pode-se perceber a emoção sentida pelas crianças ao realizarem as atividades propostas.

EPISODIO 7: Aula ao vivo (Zoom)

$\mathrm{Na}$ aula, a partir da plataforma Zoom, conversou-se sobre a história elaborada por elas. Feitos alguns questionamentos, como: Quem reconheceu letras, sílabas, palavras, números, personagem preferido, parte da história que mais gostou (não gostou) por quê? O que mudaria, o que foi engraçado, foi melhor ver a história, sendo contada em vídeo, ou escutando os pais, o que tem relação com os dias de hoje, o que tem relação, semelhança ou diferença com outras histórias etc. Tentouse começar a situação desencadeadora. Foi anotado tudo para proceder na videoaula, encaixando o conteúdo das apostilas. 
Seguem os diálogos das crianças:

Aluna S: profe eu encontrei PORQUINHA COM TINHA COM CASINHA. Página 3

Aluna SO: profe eu achei FILHINHOS COM CAMINHOS COM PORQUINHOS. Página 4

Aluna L: eu vi no livro PORQUINHO COM CAMINHO COM LIGEIRINHO. Página 6

Aluna E: profe tem na página 7 DIVERTIDO COM RÁPIDO COM QUANDO.

Aluno B: profe a mãe falou que tem ENTRAR COM SOPRAR COM VOAR. Página 10

Aluno A: profe também vi RESOLVEU COM SOPROU COM VOOU. Página 12

Aluno L: profe os numeros 1,2 e 3 de 3 porquinhos

Aluna S: profe minha mãe leu PRIMEIRO, SEGUNDO, TERCEIRO que é numero. Né?

Aluna S: profe os porquinhos VIVEM NA NATUREZA, NO INTERIOR, NO SITIO, NA FAZENDA. Né?

Aluno A: profe NÓS VIVEMOS NA CIDADE, NO SITIO TAMBÉM, NA PRAIA.

Falaram muito que as palavras terminavam iguais, são rimas. Foi pedido que registrassem para próxima aula.

$\mathrm{Na}$ verdade, no momento dos diálogos, um falou e os outros foram atrás da mesma ideia. Não era o que se esperava, no entanto, assim como em sala de aula, presencialmente, isso pode acontecer, no ensino remoto não seria diferente. Talvez possa se achar um outro meio de desencadear essa atividade. 
Figura 9 - A participação das crianças pela plataforma Zoom.

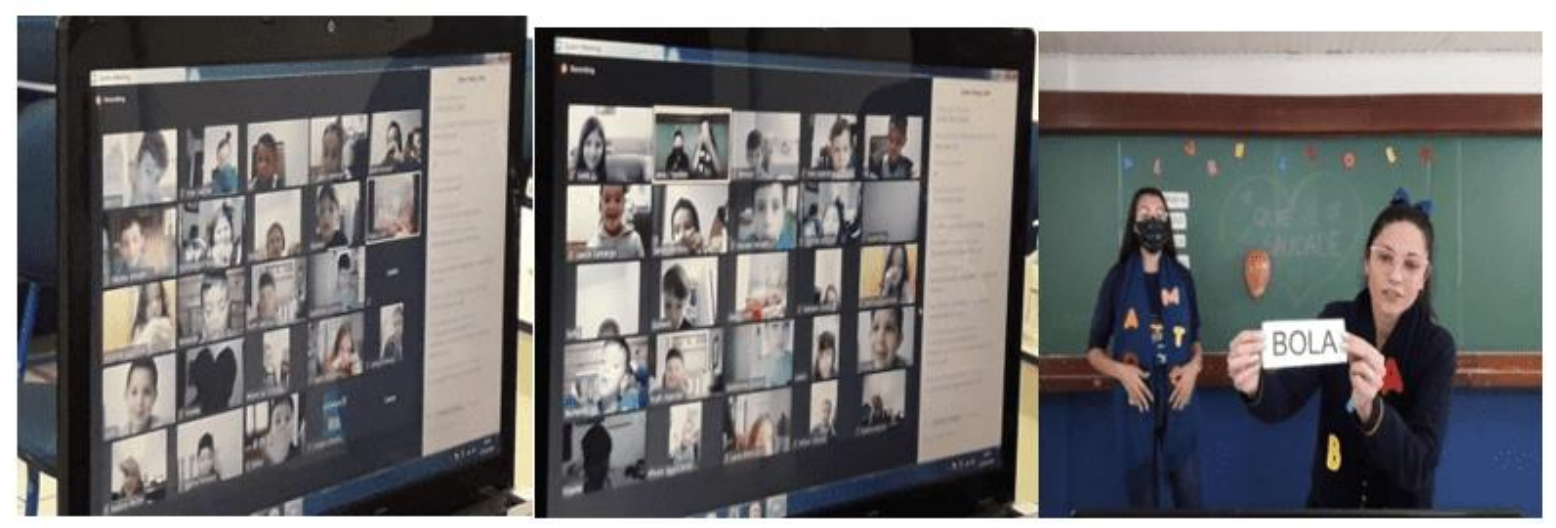

Fonte: arquivo pessoal.

A Figura 9 apresenta a participação das crianças na aula preparada para ser disponibilizada via plataforma Zoom.

EPISODIO 8: aula de português

Analisando as respostas das crianças, da aula anterior, a maioria falou de rima, que as palavras tinham a mesma terminação. Então foi gravada uma videoaula para o portal da escola com as páginas do material (apostila de português) em que falava sobre o tema para ser trabalhado.

RC: 98351

Disponível em: https://www.nucleodoconhecimento.com.br/educacao/storytelling 
Figura 10 - Videoaula sobre o tema a ser trabalhado

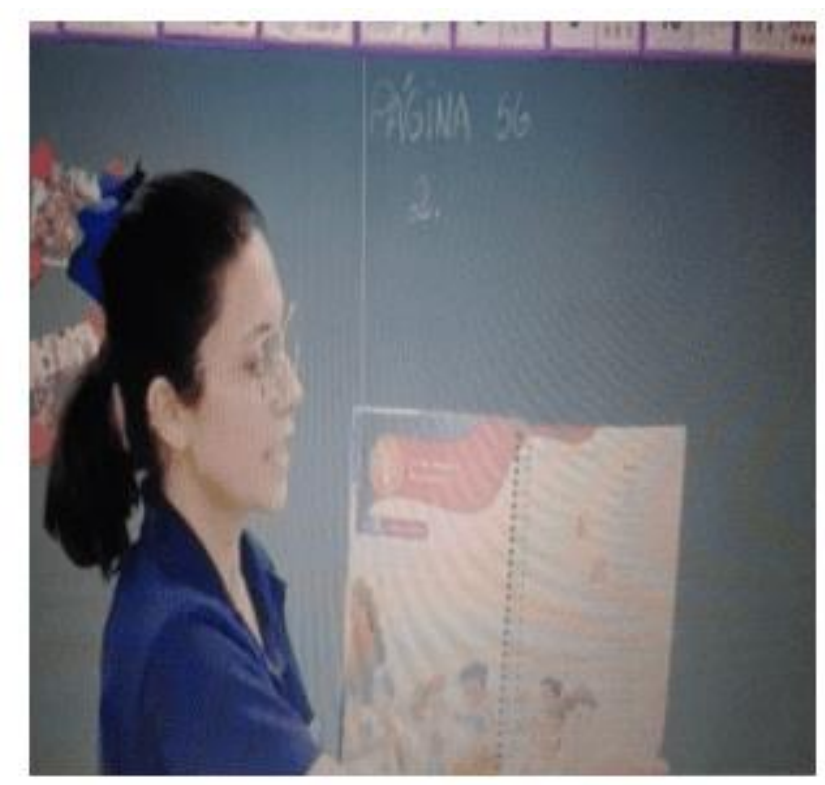

Fonte: arquivo pessoal.

Pode ser visto pela Figura 10 o momento em que são apresentadas explicações sobre o tema, no caso, as rimas.

EPISODIO 9: retorno aula de Língua Portuguesa

As crianças enviaram suas atividades, conforme foi explicado em videoaula.

RC: 98351

Disponível em: https://www.nucleodoconhecimento.com.br/educacao/storytelling 
Figura 11 - Envio das crianças sobre a aula de Língua Portuguesa.

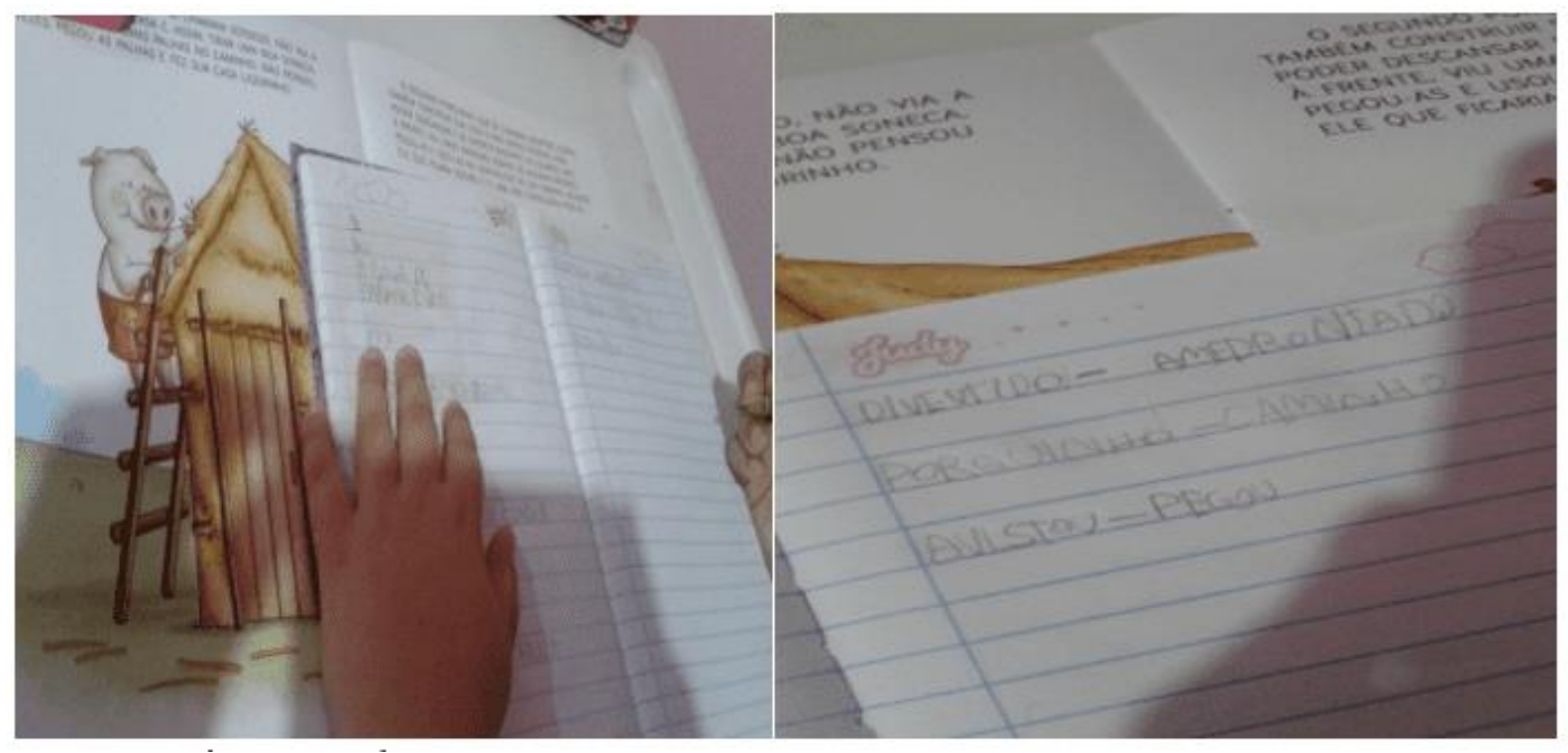

Fonte: arquivo pessoal.

Acima, expõe-se a Figura $11 \mathrm{com}$ imagens das crianças fazendo as atividades propostas.

EPISODIO 10: Aula de matemática

$\mathrm{Na}$ aula de matemática, analisando as respostas delas, uma parte falou sobre números naturais e a outra sobre números ordinais. 
Figura 12 - Videoaula com explicações sobre numeração.

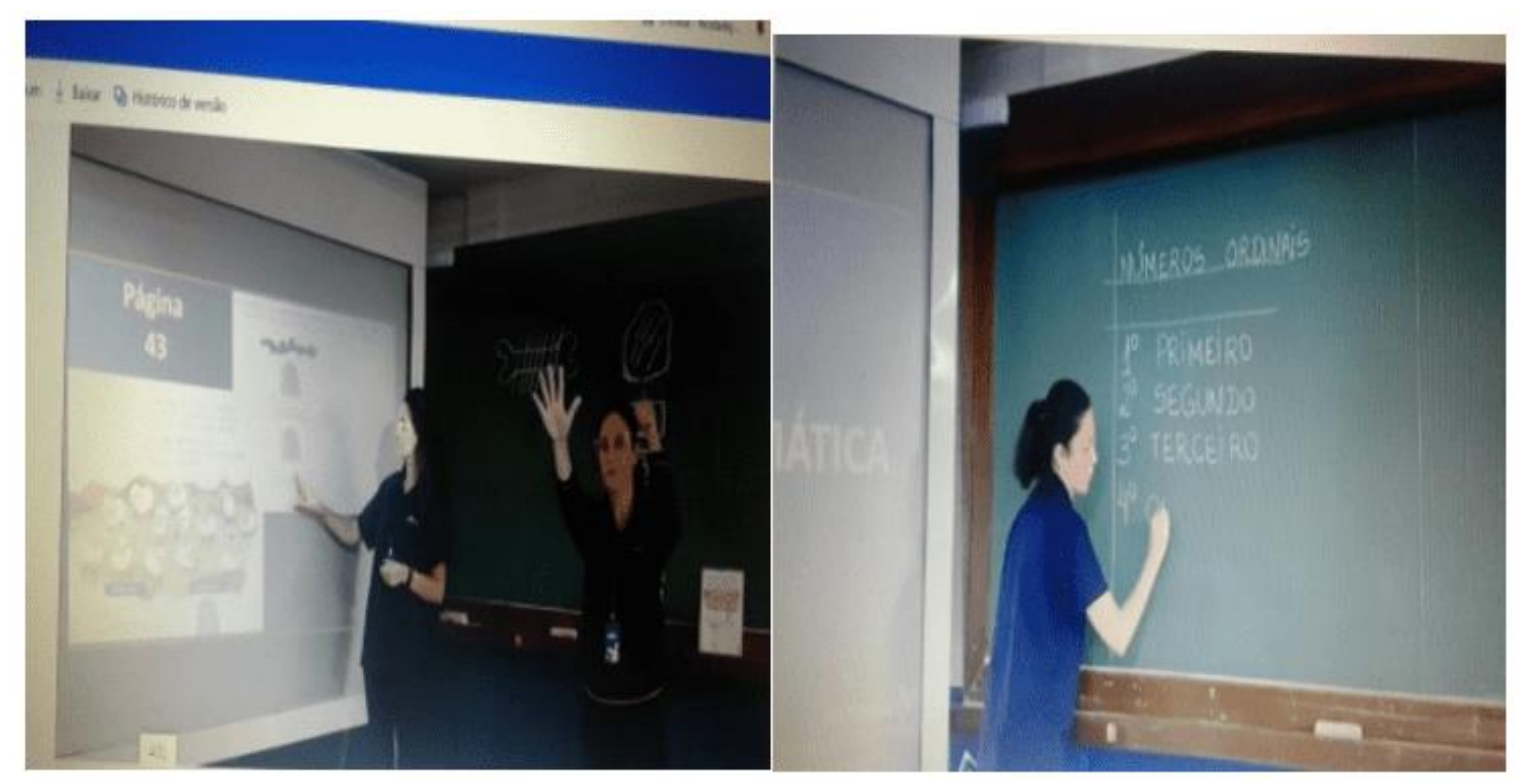

Fonte: arquivo pessoal.

Então, foi gravado uma videoaula para o portal da escola com páginas do material (apostila de matemática) a ser trabalhada sobre numeração, como pode ser visto na Figura 12.

EPISODIO 11: Retorno da aula de matemática 
Figura 13 - Apresentação das atividades sobre numeração.

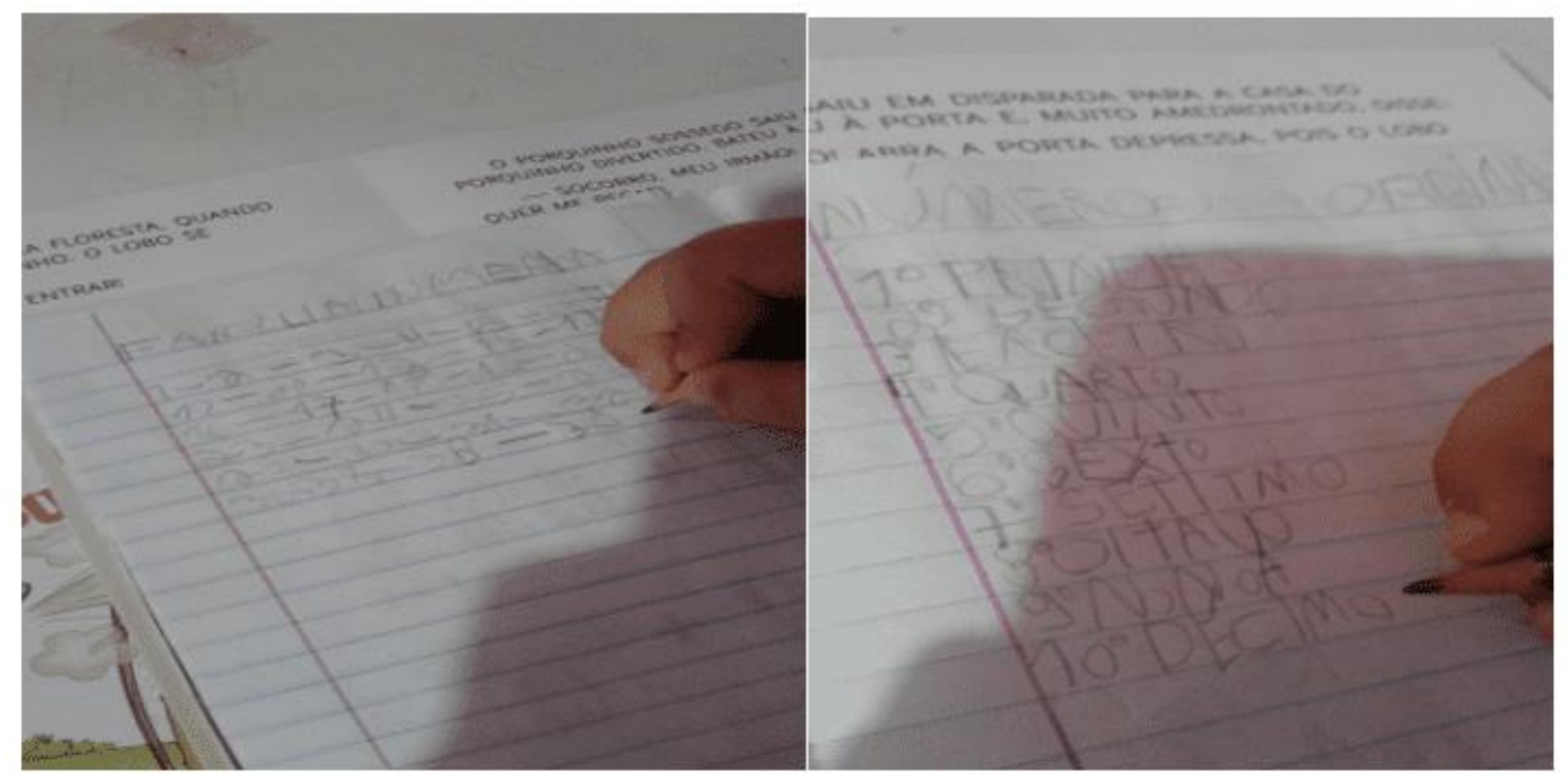

Fonte: arquivo pessoal.

Com base nas explicações da videoaula, as crianças desenvolveram as atividades sobre numerais. A Figura 13 mostra esse momento de duas crianças.

EPISODIO 12: Aula de natureza e sociedade

$\mathrm{Na}$ aula de natureza e sociedade, foram analisadas as respostas das crianças em relação a questões apresentadas, grande parte falou sobre o lugar onde vive.

RC: 98351

Disponível em: https://www.nucleodoconhecimento.com.br/educacao/storytelling 
Figura 14 - Explicações sobre Natureza e Sociedade.

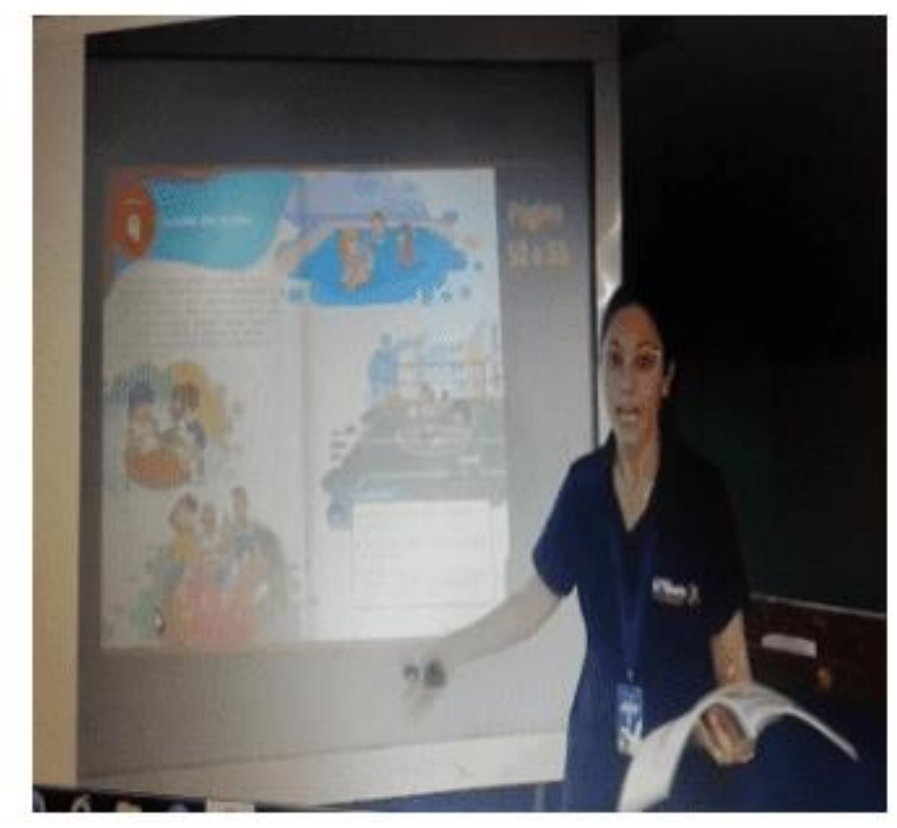

Fonte: arquivo pessoal.

Em seguida, foi gravada uma videoaula que ficaria disponível no portal da escola, com páginas do material (apostila de natureza e sociedade) que falava sobre onde se vive, cidade, rua, família etc. Vide a Figura 14.

EPISODIO 13: Retorno da aula de natureza e sociedade

Foi pedido às crianças enviaram suas atividades, conforme o que foi proposto na apostila. 
Figura 15 - Retorno das crianças sobre Natureza e Sociedade.

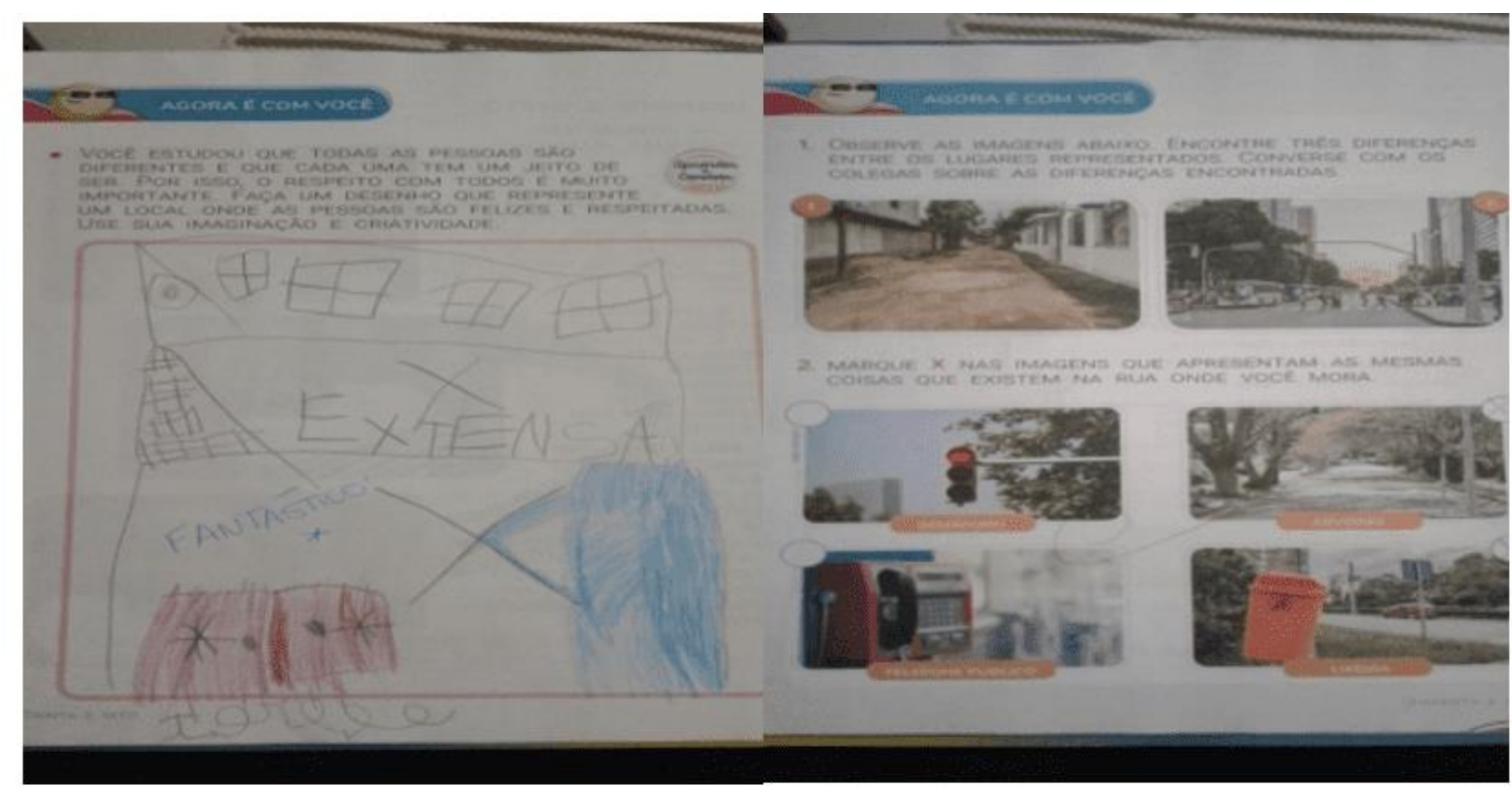

Fonte: arquivo pessoal.

$\mathrm{Na}$ aula de Natureza e Sociedade, nas atividades propostas, as crianças usaram criatividade ao dares suas respostas. Vide Figura 15.

EPISODIO 14: Xfone (whatsapp)

Realizou-se uma ligação, para uma conversa individual pelo celular, chamada de voz e de vídeo. Uma conversinha amigável, para matar um pouquinho a saudade e instigar a curiosidade das crianças sobre a história estudada (conversa individual), sempre perguntando sobre hipóteses, a partir da ilustração, em relação ao texto, palavras escritas etc. $\mathrm{O}$ que eles viram ou ouviram sobre os três porquinhos. Quais áreas do conhecimento se poderia trabalhar? O que eles aprenderam em português, Matemática etc.

Assim foram as conversas ao telefone:

Aluna S: profe não entendo porque os porquinhos tinha de sai de casa. Que mamãe malvada. Eles podem ficar com ela para cuidar dela quando velhinha.

Aluna SO: o tia, na verdade eles não foram para outro lugar, ficaram na floresta, tinha que mudar de cidade para o lobo não pegar. 
Aluna L: profe um era vadio fez bem rápido e depois correu para o esperto. Viu! Agente tem de cuidar da nossa casa.

Aluna E: pro a mãe disse que meu irmão vai ser assim, ele vai embora fazer faculdade, morar sozinho um dia, tadinho!

Aluno B: profe a mãe falou que tem que tomar cuidado com estranhos, o lobo era o estranho.

Aluno A: profe na floresta não tem só lobo, tem onça, eles deviam morar em outro lugar melhor.

Aluno L: o tia, na minha vó tem porco e eles são bem bonzinhos e vão morar com ela.sabia, ela cuida deles.

Aluna S: profe minha mae disse que os porquinhos tinha de ter morado dês doinicio junto, mais eu falei daí eles não vão aprende as coisa.

Aluna S: profe os porquinhos vivem na fazenda e sitio tinha que fazer a casa deles assim para viver melhor.

Aluno A: o tia agente come carne de porco, tadinho, NÉ! Eles tem de viver e viver bem, NÉ!

Figura 16 - Anotações sobre as questões levantadas pelas crianças.

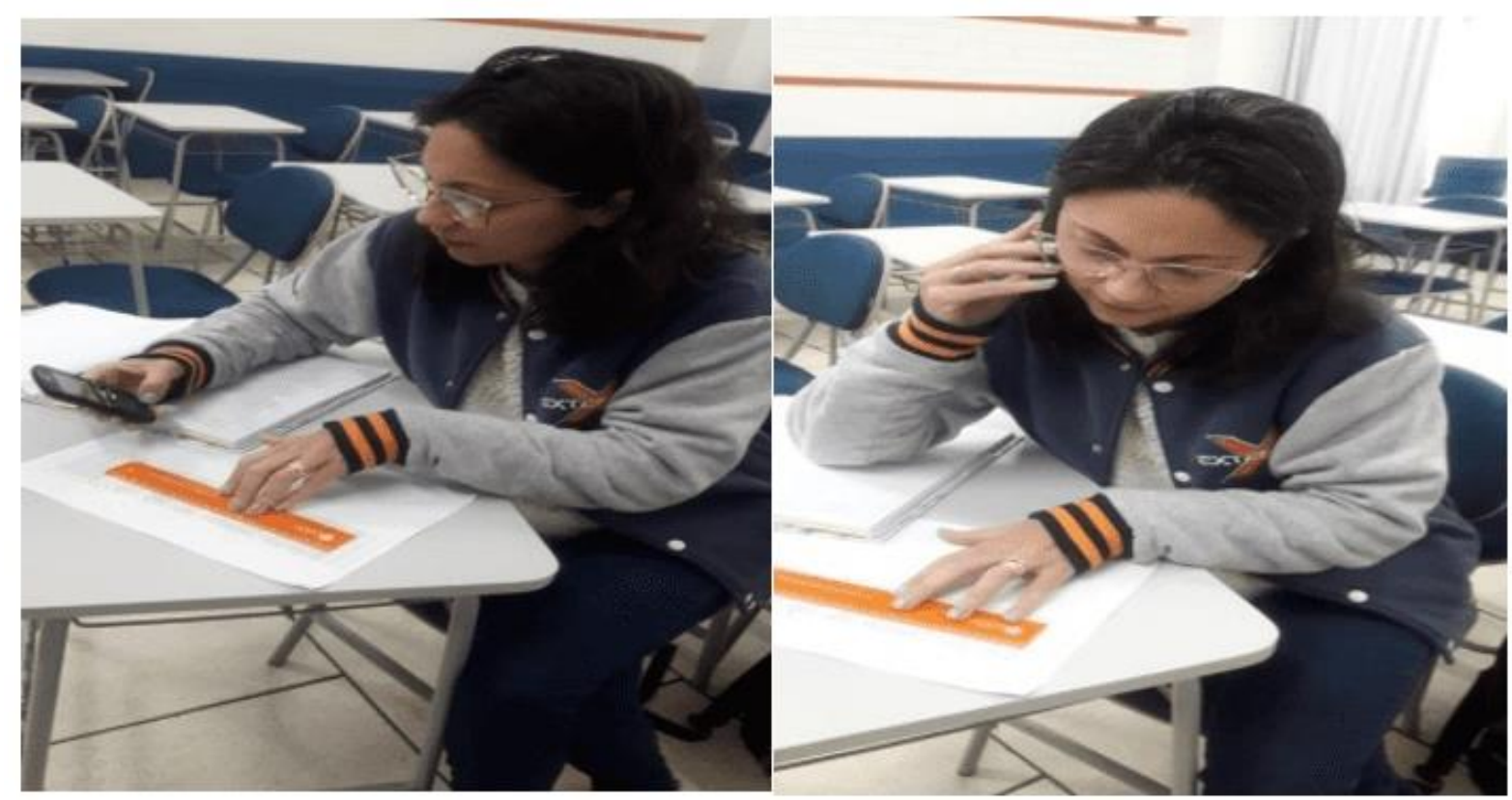

Fonte: arquivo pessoal. 
Tudo anotado, para mais tarde fazer um planejamento de como trabalhar isso, mais um desafio. Uma forma de desencadear essa situação dos porquinhos.

\section{EPISODIO 15: Situação desencadeadora}

A situação desencadeadora proposta era resolver um problema, onde os porquinhos poderiam morar? Foi o que a maioria queria. Então, resolveu-se que seria construída uma maquete do ambiente. Para isso, foi gravada uma videoaula explicando como montar uma maquete e os materiais que poderiam utilizar, de preferência recicláveis. Deixou-se a criatividade por conta das crianças. O melhor lugar para se estar! O lugar para viver bem!

A educação tem de surpreender, cativar, conquistar os alunos a todo o momento. A educação precisa encantar, entusiasmar, seduzir, apontar possibilidades e realizar novos conhecimentos e práticas. A escola é um dos espaços privilegiados de elaboração de projetos de conhecimentos, de intervenção social e de vida. É um espaço privilegiado de experimentar situações desafiadoras do presente e do futuro, real e imaginário.

Para Moran (2012, p. 28):

As mudanças na educação dependem, em primeiro lugar, de termos educadores maduros intelectual e emocionalmente, pessoas curiosas, entusiasmadas, abertas, que saibam motivar e dialogar. Pessoas com as quais valha a pena entrar em contato, porque dele saímos enriquecidos.

O verdadeiro professor é humilde e confiante, presta atenção no que as crianças dizem e acredita nelas. Mostrar o que sabe, ouvindo opiniões, o professor deve estar atento ao que não sabe, ao novo, o que muitas vezes são elas, as crianças que ensinam. Inovar na educação quer dizer deixar as crianças curiosas, mais motivadas, consequentemente, aprendem e ensinam, avançam mais, ajudam o professor a ajudá-las. 
Na educação, para Moran (2012, p. 31): “[...] o mais importante não é utilizar grandes recursos, entretanto, desenvolver atitudes comunicativas e afetivas favoráveis e algumas estratégias de negociação com os alunos".

Figura 17 - Preparando a maquete

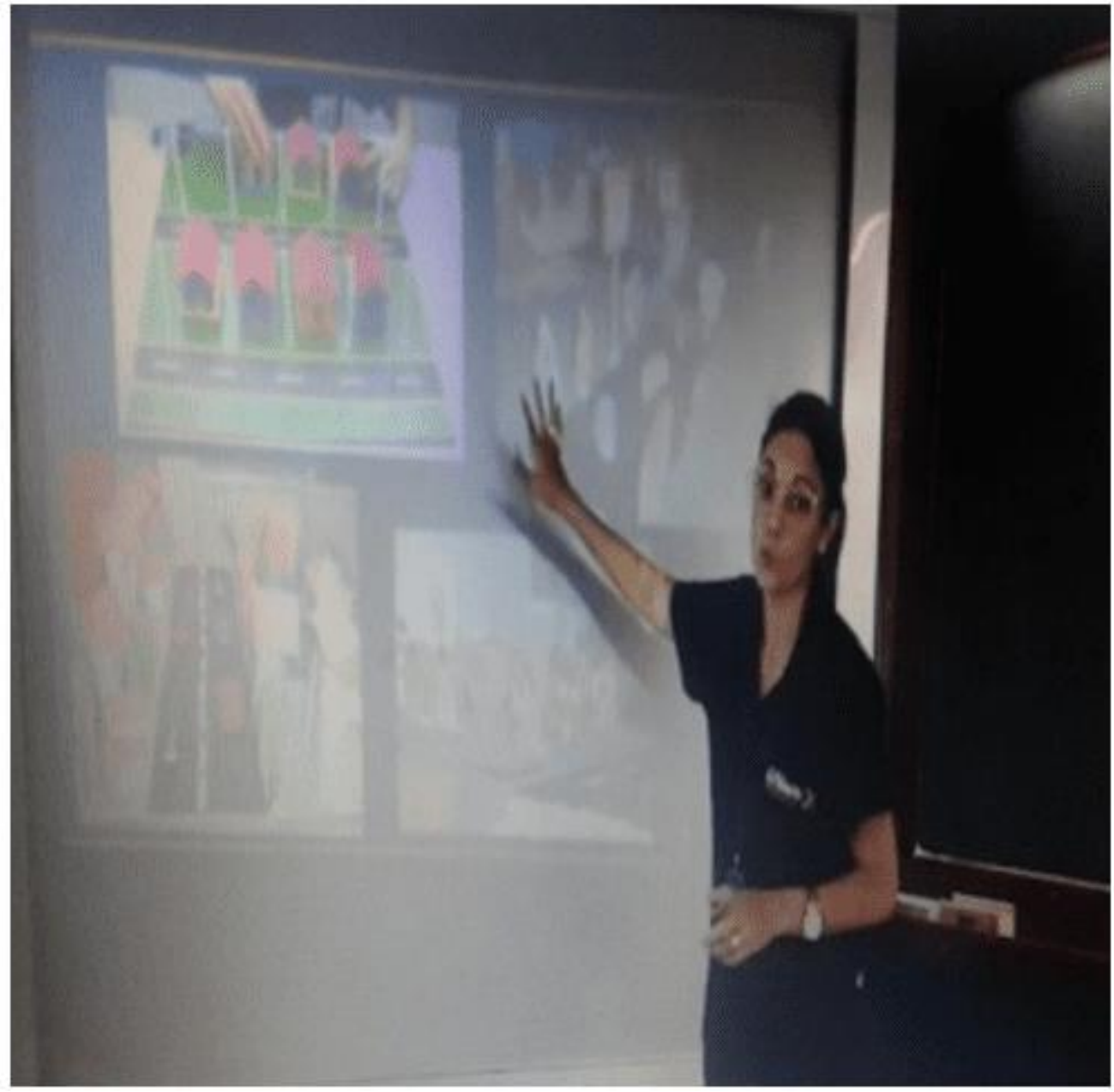

Fonte: arquivo pessoal.

$\mathrm{Na}$ Figura 17, pode ser visualizado o momento das explicações sobre o desenvolvimento das maquetes pelas crianças.

EPISODIO 16 Maquete

RC: 98351

Disponível em: https://www.nucleodoconhecimento.com.br/educacao/storytelling 
Cada criança começou a desenvolver a sua maquete, de acordo com a sua imaginação.

Figura 18 - Construindo maquetes.

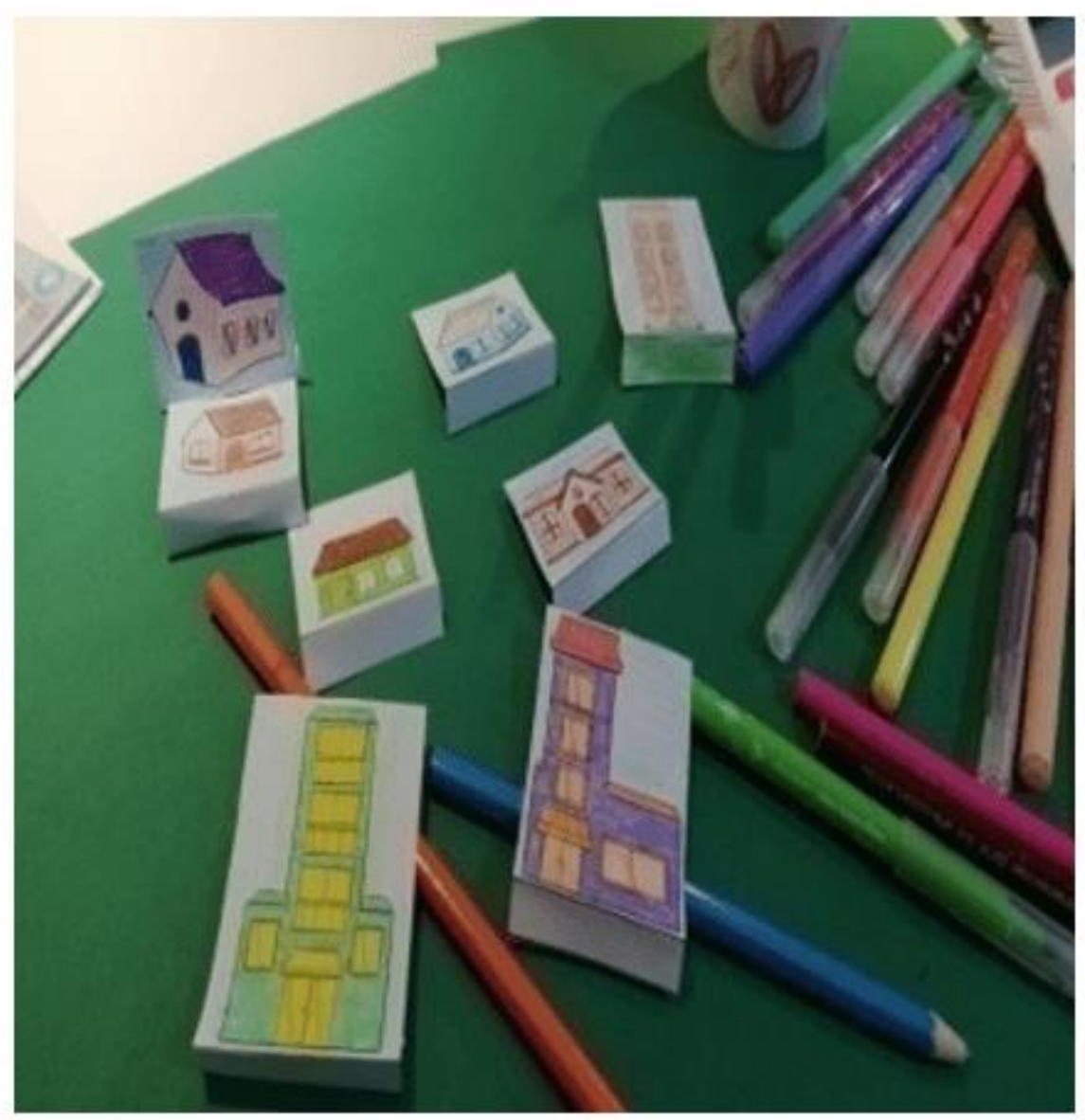

Fonte: arquivo pessoal.

Algumas crianças utilizaram anexos de recortes que há na própria apostila.

RC: 98351

Disponível em: https://www.nucleodoconhecimento.com.br/educacao/storytelling 
Figura 19 - Uso de anexos na construção das maquetes.

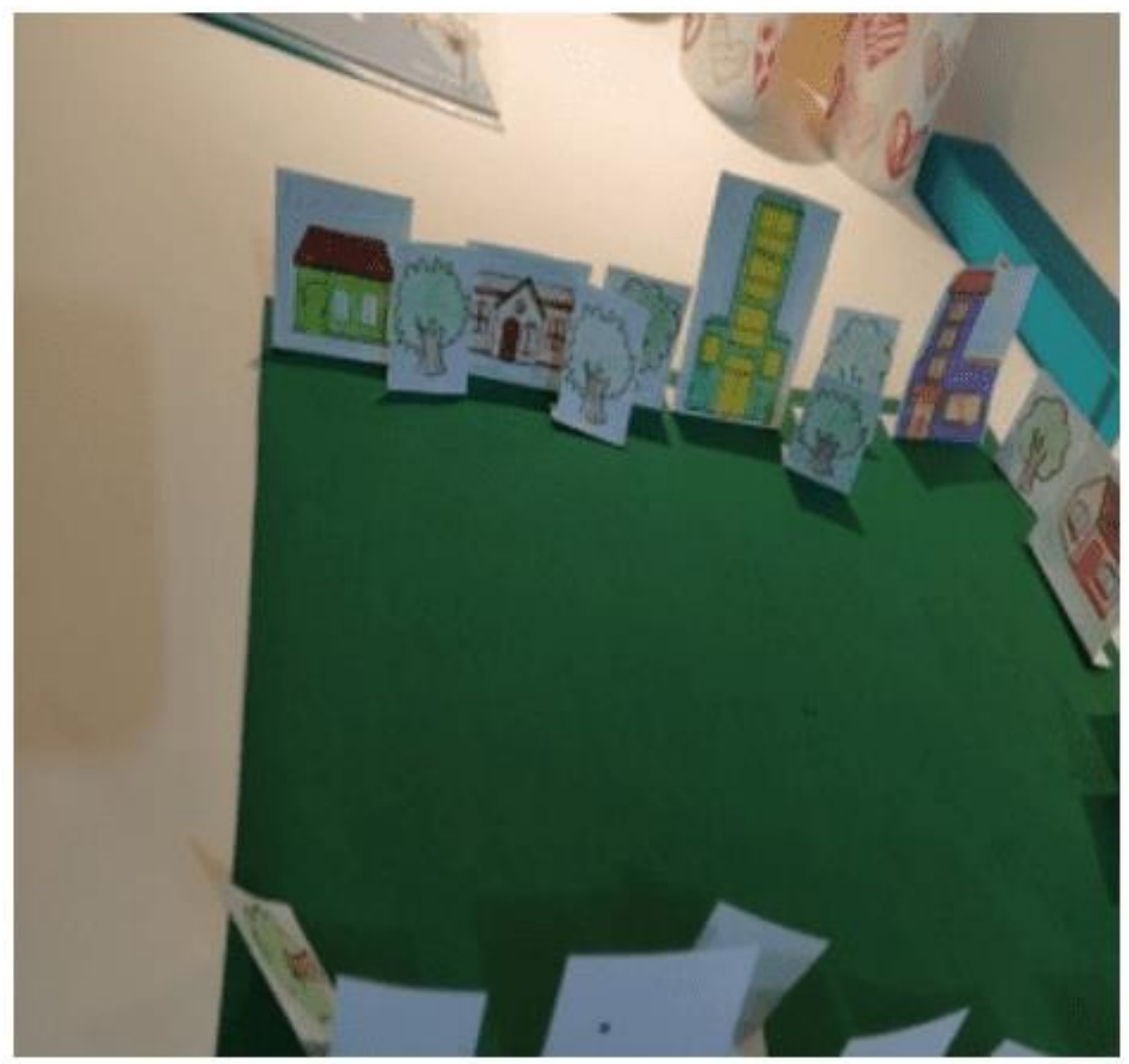

Fonte: arquivo pessoal.

Outras disseram que qualquer lugar estaria bom, o importante era que eles ficassem perto um do outro, para, em caso de uma emergência, um ajudar o mais próximo.

RC: 98351

Disponível em: https://www.nucleodoconhecimento.com.br/educacao/storytelling 
Figura 20 - Maquetes com outros materiais.

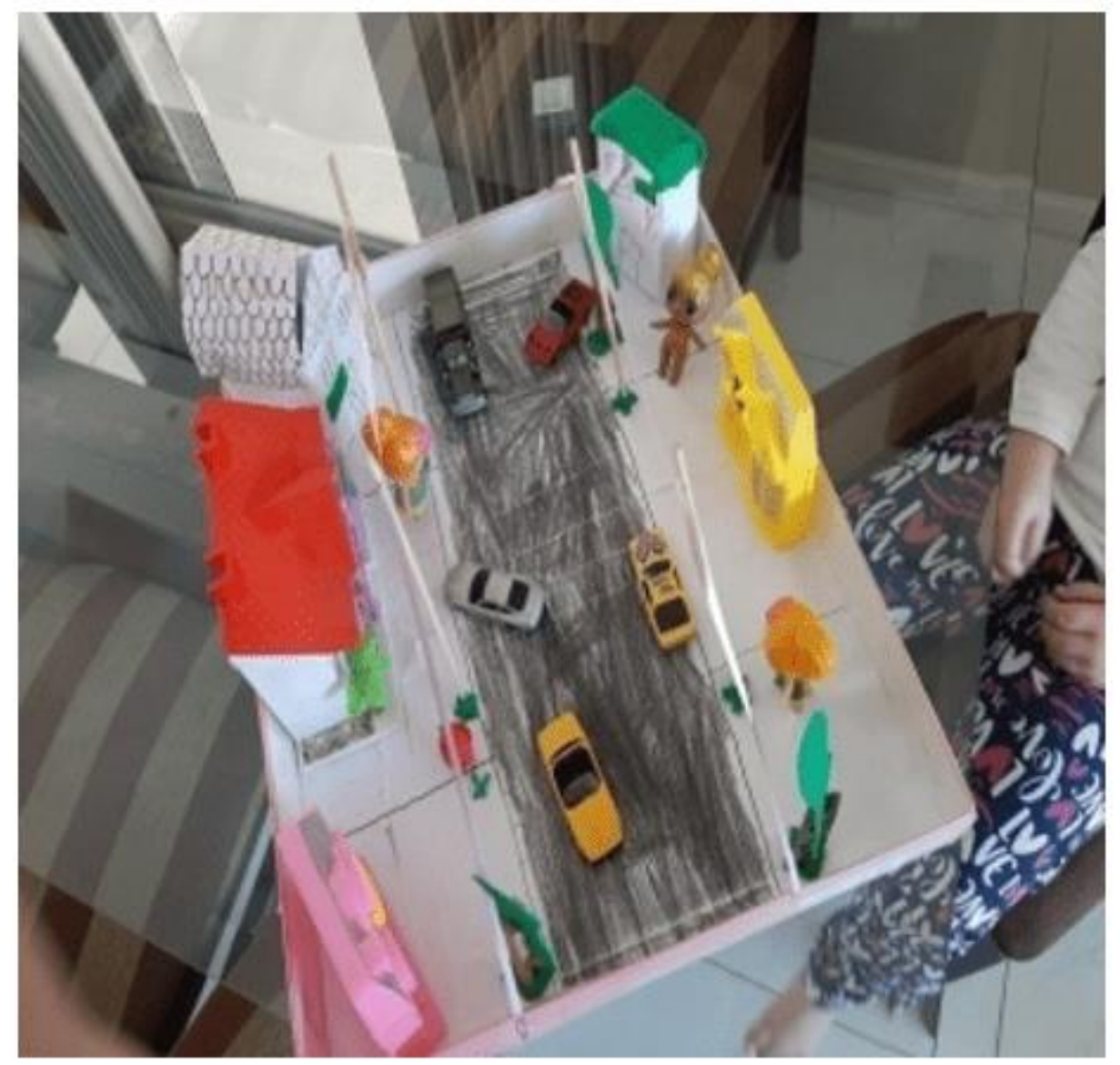

Fonte: arquivo pessoal.

A maioria das meninas fizeram a maquete da sua casa, pois disseram que o melhor lugar para se viver feliz, é na sua casa.

RC: 98351

Disponível em: https://www.nucleodoconhecimento.com.br/educacao/storytelling 
Figura 21 - Maquetes com outros materiais.

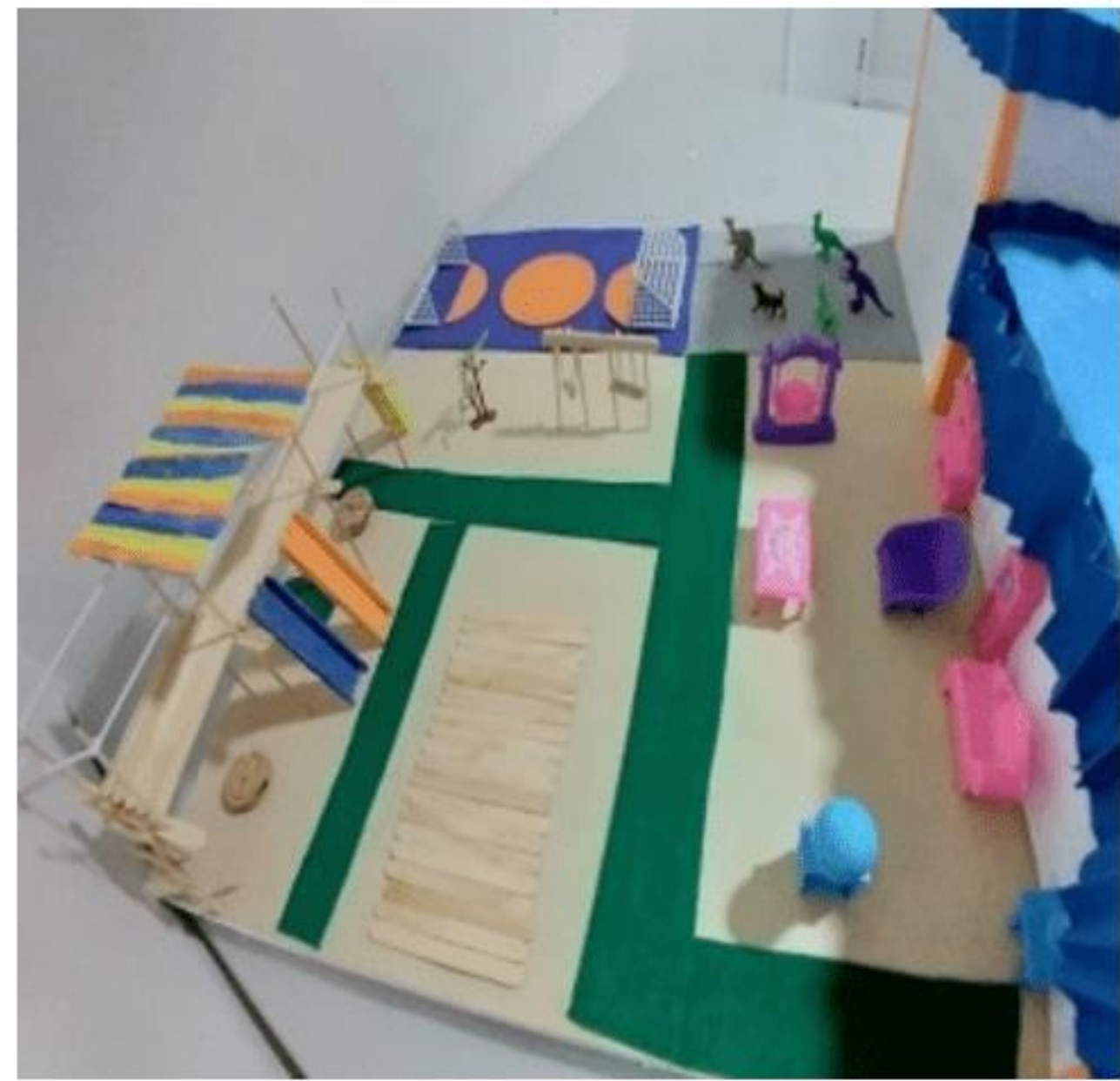

Fonte: arquivo pessoal.

Houve meninos que falaram que a escola é o melhor lugar do mundo para estar e ser feliz.

\section{CONSIDERAÇÕES SOBRE OS EPISÓDIOS}

O papel da escola é "tirar o aluno do lugar". Movimentar ideias! Embora em momento de pandemia sem frequentar a escola, foram planejadas aulas, utilizando as metodologias ativas, para que a escola fosse até as crianças. Por conseguinte, foram propostas atividades para que as crianças se sentissem ativas, usando sua criatividade e espontaneidade, sem deixar de usar a matéria didático, sempre com o 
objetivo de praticar a leitura e a escrita. Utilizando os recursos digitais ao nosso favor: telefone, WhatsApp, zoom, portal online etc.

Nesse período de pandemia, foi importante para que se elaborasse uma outra forma de avaliação. A partir da observação do ambiente virtual, percebeu-se que a avaliação não poderia ser feita, conforme é feito no ensino presencial, nos moldes tradicionais, a cada final de conteúdo, uma avaliação. Seria importante que se realizassem atividades que se somassem, que se integrassem e que, ao longo do ano, fossem concluídas

Convém ressaltar que o importante é equilibrar, planejar e aceitar as mudanças.

Para Moran (2012, p. 124):

Acho que toda avaliação, virtual ou presencial, deve ser continuada; o que significa que devemos avaliar não apenas um questionário de perguntas e respostas previamente elaboradas; devemos levar em conta também a participação do aluno, com dúvidas, comentários, críticas e atitudes em relação aos conteúdos abordados e em relação ao grupo e ao professor.

Respeitar esse processo de ensino aprendizagem, na alfabetização, analisando e avaliando a evolução, favorecem às crianças e aos professores, pois ambos manifestam sua criatividade, dando liberdade para expor ideias, conforme o Currículo Básico do Território Catarinense (2019, p. 153):

\begin{abstract}
Nessa concepção, o docente pode acompanhar o processo ensino aprendizagem do sujeito e, a partir desse acompanhamento, retomar o que não foi aprendido, (re)planejar, de modo a garantiras aprendizagens, na perspectiva da formação integral. Desse modo, a "[...] avaliação deve servir como um instrumento de inclusão e não de classificação e/ou exclusão. Deve ser um indicador não apenas do nível de desenvolvimento do estudante, como também das estratégias pedagógicas e das escolhas metodológicas do professor. (SANTA CATARINA, 2014, p. 46).
\end{abstract}

Foram dadas algumas explicações sobre os termos alfabetização e letramento para os pais. Dessa forma, quando trabalhassem com as crianças em casa, tivessem cuidado e didática, do que a professora contaria agora com eles. Muitas vezes os pais dizem que é a escola que ensina, não sabendo que eles ensinam muito. 
A alfabetização é um processo de aquisição do sistema alfabético e ortográfico (transformar sons em letras, e letras em sons, reconhecer letra, juntar sílabas e aprender como se usar o lápis, a forma de segurar, noção de escrita de cima para baixo e da esquerda para a direita, cuidado com a margem, parágrafo, linha, noção de espaço o dedinho entre uma palavra e a outra, falar adequadamente para o aluno olhando olho no olho), esses formam os elementos fundamentais, na observação da avaliação.

O letramento é um processo de desenvolvimento de habilidade do uso de tecnologia da escrita (aprender a produzir textos, ler e compreender, ajustar o texto para quem escreve e com que objetivo escreve saber lidar com diferentes gêneros e interpretar). Então, avaliar a criança, respeitando o retorno dos pais, pois foi com eles que as crianças aprenderam em casa, seguindo as suas orientações.

Tanto a alfabetização quanto o letramento são aprendizagens distintas. Trata-se de processos cognitivos de natureza diferente e, como tal, a aprendizagem e o ensino de ambos acontecem de forma diversa. Apesar disso, "[...] as ciências em que se baseiam esses processos e a pedagogia por elas sugeridas evidenciam que são processos simultâneos e interdependentes". (SOARES, 2020, p. 27).

Importa considerar que para o uso da língua em situações reais, ou seja, nas práticas sociais de escrita, as crianças não necessariamente precisam estar alfabetizadas, ou seja, a alfabetização não é condição para o letramento. Nesse envolvimento com as práticas de leitura e de escrita é que a criança aprende a ler e a escrever. (SOARES, 2020).

\section{CONSIDERAÇÕES FINAIS}

Este artigo teve como objetivo analisar como Storytelling pode ser uma ferramenta para o aprendizado ativo, de forma a contribuir, para que a criança, em fase inicial da alfabetização e letramento, aproprie-se dos conhecimentos e ao mesmo tempo desenvolva o gosto pela leitura e escrita. 
Para isso, desenvolveu-se uma pesquisa exploratória, com abordagem qualitativa. A pesquisa realizou-se a parit de um estudo e análise de uma investigação realizada com crianças do $1^{\circ}$ ano do ensino fundamental, classe de alfabetização

Foram utilizados canais de comunicação, como o WhatsApp, para fotos ou vídeos da realização das atividades e chamada de voz para conversar individualmente, (como AULAS).

Foram feitas videoaulas, gravadas e salvas, no portal da escola sobre a leitura de um livro, para a turma de forma lúdica. Foi explicado sobre as páginas das apostilas que seriam usadas, com a história; enviadas as sugestões de atividades e das orientações escritas, em um documento de PDF, para Xerox, (como ZOOM) sobre a participação, a interpretação e a investigação, também para a realização das atividades, depois para debater e conversar ao vivo com a turma toda.

Tudo isso aconteceu em sala de aula remota, com métodos digitais. Os pais foram fundamentais, no intercambio do conhecimento para as crianças. Elas foram protagonistas do processo de aprendizagem, os adultos também auxiliaram a professora generosamente. Aceitaram reservar um tempo para ler, e um cantinho de sua casa, para o ambiente de leitura e realização das atividades. Também organizaram os horários das aulas, para as crianças estarem on-line.

Conseguiu-se manter a ideia da intervenção do começo ao fim, o foco inicial era criar uma mascote, para aguçar o prazer pela leitura. Foram iniciadas as leituras, para que se desenvolve-se o processo de leitura e de escrita, na alfabetização e letramento, por meio de uma metodologia ativa com uso de materiais digitais, por conta da distância.

A realização das atividades foi de maneira interdisciplinar, pois mesmo a criança aprendendo os números, olhando as páginas nos livrinhos, ela está lendo e escrevendo. Não é só em matemática que se fala de números, e sim em durante todo o processo. Competiu ao professor estabelecer essa ligação entre conceitos 
trabalhados em diversas áreas, usando a leitura e a escrita, que são fundamentais, para a comunicação em diversas situações.

Os professores não estavam preparados, para esse período de pandemia, entretanto, contou-se com muita ajuda, houve contato com diferentes culturas e costumes das famílias.

Ensinar a ler e escrever, ensinar a entender o que lê, é um processo demorado e árduo e contínuo. É preciso que sejam oferecidos cursos de formação para os professores, de forma a possibilitar a eles a busca de mais e mais conhecimentos. Porque é desses conhecimentos, dessas novas metodologias, como por exemplo, a Storytelling que vão tornar suas aulas significantes para os alunos.

A questão principal para essa pesquisa foi motivar as crianças para que adquirissem a leitura e a escrita, na alfabetização e no letramento, oportunizando a elas um aprendizado de excelência, mesmo a distância. Trabalhou-se não só a parte sistêmica da ortografia, mas também se ela estava aprendendo o porquê e para quê.

Por meio da narrativa de uma história clássica, a criança pode perceber, reconhecer e vivenciar o processo de alfabetização e de letramento. Caminhos que buscaram despertar a paixão e o prazer pela leitura, em primeiro lugar. Em razão disso, fez com que a criança se sentisse segura de levantar hipóteses e dar sua própria opinião, trazendo a imaginação e o conhecimento à tona, ligando o conteúdo gramatical com o cotidiano, sempre relacionando o que escutou, leu e escreveu.

Isso posto, pôde-se verificar que a storytelling pôde ajudar, na construção dos conteúdos e contribuir com a aquisição da leitura, fazendo a criança entender os conteúdos de forma diferente e lúdica. É fundamental para o professor planejar suas aulas de forma que o processo de aprendizagem se efetue, usando métodos interdisciplinares e metodologias ativas. O professor que utiliza material lúdico, como histórias, músicas, diversos gêneros discursivos, consegue ensinar, alfabetizar e o letrar de uma maneira leve, deixando as crianças apaixonadas pelo ato de ler, 
despertando a curiosidade pela escrita. Cada criança aprende de um jeito e o professor precisa estar atento ao entendimento e a evolução de cada uma.

Por fim, afirma-se que o objetivo desta pesquisa foi alcançado, professores conectados, pais engajados e crianças alfabetizadas.

\section{REFERÊNCIAS}

BACICH, Lilian: MORAN, José. Metodologias ativas para uma educação inovadora: uma abordagem teórico-prática/ Organizadores, Lilian Bacich, José Moran. Porto Alegre: Penso, 2018.

CARVALHO, Marlene. Alfabetizar e letrar: um diálogo entre a teoria e a prática. 7ª̣ . ed. Petrópolis, RJ: Vozes, 2010.

FARIA, Inglide Graciele de; FLAVIAN, Sebastiana de Lourdes Lopes; GUIMARÃES, Maria Severina Batista Guimarães; FALEIRO, Wender. A influência da contação de histórias na Educação Infantil. Revista Mediação. Pires do Rio - GO, v. 12, n. 1, p. 30-48, jan.- dez. 2017.2 Disponível em: https://www.revista.ueg.br/index.php/mediacao/article/view/6368. Acesso em: 20 out. 2020.

FERNANDES, Maria. Os segredos da alfabetização. 2. ed. São Paulo: Cortez, 2010.

FERREIRO, Emilia. Reflexões sobre a alfabetização/ Emilia Ferreiro. Tradução Horácio Gonzales (et. al.). 18ª . ed. São Paulo: Cortez: Autores Associados, 1991;

FREIRE, Paulo. A importância do ato de ler: em três artigos que se completam. São Paulo: Autores Associados: Cortez, 1989.

FREIRE, Paulo. Pedagogia da autonomia: saberes necessários à prática educativa. São Paulo: Paz e Terra, 1996. 
GALVÃO, Andréa. LEAL, Telma Ferraz. Há lugar ainda para métodos de alfabetização? Conversa com professores(as). In: BRASIL. Ministério da Educação. Alfabetização: apropriação do sistema de escrita alfabética. Org. Artur Gomes Morais, /Eliana Borges Correia de Albuquerque, Telma Ferraz Leal. Belo Horizonte: Autêntica, 2005. Disponível em: http://www.serdigital.com.br/gerenciador/clientes/ceel/arquivos/20.pdf. Acesso em: 20 out. 2020.

KRAMER, Sonia. Alfabetização: "Dilemas da Prática”. In: KRAMER, Sonia et al (org). Rio de Janeiro: Ltda., 1986.

LEITINHO, Karine Lopes. Os Três Porquinhos / (adaptação). 3ạ. ed. Fortaleza: Sistema Ari de Sáde Ensino. 2016. (Coleção Clássicos Infantis).

MORAN, José Manuel. A educação que desejamos: novos desafios e como chegar lá. 5ª Ed. - Campinas, SP: Papirus, 2012.

PALACIOS, Fernando. TEREZZO, Martha: O guia completo do Storytelling. Rio de janeiro: Alta Books, 2016.

REGO, Tereza Cristina. Vigotsky: Uma perspectiva Histórico Cultural da educação. Petrópolis, RJ. Vozes, 1995.

SANTA CATARINA. Secretaria de Estado da Educação. Proposta Curricular de Santa Catarina: formação integral da Educação Básica. Estado de Santa Catarina: Secretaria de Estado da Educação, 2014.

SANTA CATARINA. Secretaria de Estado da Educação. Currículo Base da Educação Infantil e do Ensino Fundamental do Território Catarinense. Florianópolis: Secretaria de Estado da Educação, 2019.

SHOLZE, Lia; ROSING, Tânia M.K (org.). Teorias e práticas de letramento. Brasília, DF: Inep, 2007. 
SOARES, Magda. Letramento e alfabetização: as muitas facetas. Revista Brasileira de Educação. São Paulo, n. 25, p. 5-17, jan./abr. 2004.

SOARES, Magda. Alfaletrar: toda criança pode aprender a ler e escrever. São Paulo: Contexto, 2020. 352 p.: II.

XAVIER, Adilson. Storytelling [recurso eletrônico] 1르 ed. Rio de Janeiro: Best Seller, 2015.

Enviado: Dezembro, 2020.

Aprovado: Outubro, 2021. 